\title{
The Pliocene and Pleistocene fluvial evolution in the northern Upper Rhine Graben based on results of the research borehole at Viernheim (Hessen, Germany)
}

\author{
Christian HoselmanN ${ }^{*}$
}

\begin{abstract}
The research borehole drilled in 2006 by the Hessian Agency for the Environment and Geology (HLUG) north of Viernheim (Hessisches Ried) reached a total depth of $350 \mathrm{~m}$, and penetrated high resolution fluviatile and limnic-fluviatile sediments ( 0 to $225 \mathrm{~m}$ ) of Pleistocene age, and partially highly pedogenically overprinted limnic-fluviatile sands, clays and silts of Pliocene age (225 to $350 \mathrm{~m}$ ). The Pliocene sediments tend to be sourced locally. The sediments repeatedly show sourcing from the Odenwald which is characterised by a high percentage of green hornblende in the heavy mineral fraction. As part of the Heidelberg Basin research programme, one of the main purposes of this borehole was to analyse the Pleistocene "Normal Facies" of the northern Upper Rhine Graben, i.e. a sedimentary sequence subject to minimum disturbance, largely unaffected during the Pleistocene by material sourced from the graben margins or smaller tributaries.

The Pleistocene sedimentary sequence consists of three units: a thin horizon with reworked Pliocene material is overlain by ten cycles each beginning erosively with gravely sandy sediments and ending with siltyargillaceous to in part peat-like sediments. Internal cycles can also be identified, amongst other features. A characteristic aspect is the green-grey, strongly calcareous, micaceous and well sorted, fine to medium sands of the Rhine. These are dominated by the Rhine Group (garnet, epidote, green hornblende and alterite) in the heavy mineral fraction. These sediments are classified as the "Rhenish Facies". The upper Pleistocene sedimentary sequences at the top of the Viernheim research borehole are dominated by several fining-upward and in part coarsening-upward sequences. The deposits in this part of the well are dominated by gravel deposited by the Neckar. The heavy mineral distribution of the sand fraction reveals, however, that there was mixing with Rhenish sediments.

Weichselian to Holocene aeolian sands form the topmost part of the well section. The stratigraphic classification of the Pleistocene sedimentary sequences is still uncertain in parts. The Pliocene-Pleistocene boundary is placed at $225 \mathrm{~m}$ because of the characteristic change in facies. Due to lithostratigraphic correlations with sediments within the Lower Rhine Embayment, a larger unconformity at the depth of 225 m must be accepted. Research carried out in the area around the well indicates that the youngest fine-clastic section penetrated by the well between 39.76 and $58.55 \mathrm{~m}$ is of Cromerian age.
\end{abstract}

[Die pliozäne und pleistozäne fluviatile Entwicklung im nördlichen Oberrheingraben unter besonderer Berücksichtigung der Forschungsbohrung Viernheim (Hessen, Deutschland)]

Kurzfassung: Die 2006 durch das Hessische Landesamt für Umwelt und Geologie (HLUG) abgeteufte Forschungsbohrung nördlich von Viernheim (Hessisches Ried) hat mit einer Endteufe von 350 m hoch aufgelöst fluviatile und limnisch-fluviatile Sedimente $(0$ bis $225 \mathrm{~m}$ ) des Pleistozäns und zum Teil stark pedogen überprägte limnisch-fluviatile Sande, Tone und Schluffe des Pliozäns (225 bis 350 m) durchteuft. Die Liefergebiete der pliozänen Sedimente sind eher regional geprägt. Die Sedimente zeigen wiederholt Schüttungen aus dem Odenwald, die durch einen hohen Anteil grüner Hornblende in der Schwermineralfraktion gekennzeichnet sind. Als Teil des Forschungsprogramms „Heidelberger Becken“ zielte diese Bohrung insbesondere

\footnotetext{
* Address of author: C. Hoselmann, Hessisches Landesamt für Umwelt und Geologie, Postfach 3209, D65022 Wiesbaden, Germany. E-Mail: christian.hoselmann@hlug.hessen.de
} 
im Pleistozän auf die „Normalfazies“ des nördlichen Oberrheingrabens ab, das heißt: auf eine möglichst ungestörte Sedimentabfolge, die im Pleistozän Schüttungen von den Grabenrändern oder kleineren Zuflüssen weitestgehend ausschließt.

Die pleistozäne Sedimentabfolge besteht aus drei Einheiten: über einem geringmächtigen Horizont mit aufgearbeitetem pliozänen Material folgen zehn Zyklen, die erosiv mit kiesig sandigen Sedimenten einsetzen und mit schluffig-tonigen bis zum Teil torfigen Ablagerungen abschließen. Mitunter sind interne Zyklen zu erkennen. Charakteristisch sind grünlich-graue stark carbonatische, glimmerführende und gut sortierte Feinbis Mittelsande des Rheins. In diesen dominiert die Rhein-Gruppe (Granat, Epidot, grüne Hornblende und Alterit) in der Schwermineralfraktion. Diese Sedimente werden als „Rheinische Fazies“ bezeichnet.

In der hangenden letzten pleistozänen Sedimentabfolge der Forschungsbohrung Viernheim bestimmen mehrere fining-upward und zum Teil coarsening-upward Sequenzen das Sedimentationsgeschehen. Die Ablagerungen dieses Profilabschnitts sind Kies dominiert, der vom Neckar geschüttet worden ist. Die Schwermineralverteilung der Sandfraktion zeigt aber an, dass es zu einer Vermischung mit rheinischen Sedimenten gekommen ist. Weichsel- bis holozänzeitliche Flugsande schließen das Profil ab.

Die stratigraphische Einstufung der pleistozänen Sedimentabfolge ist in Teilen noch unsicher. Die PliozänPleistozängrenze wird auf Grund des charakteristischen Fazieswechsels auf $225 \mathrm{~m}$ gelegt. Eine überregionale Korrelation mit Sedimenten der Niederrheinischen Bucht spricht für eine Diskordanz mit größerer zeitlicher Lücke an der Plio-Pleistozängrenze. Untersuchungen im Umfeld der Bohrung sprechen für cromerzeitliches Alter des jüngsten feinklastischen Abschnitts der Bohrung zwischen 39,76 und 58,55 m.

Keywords: Quaternary, Pleistocene, Pliocene, Cromerian Complex, fluvial sediments, heavy minerals, Carbonate, Upper Rhine Graben, Germany

\section{Introduction}

The north-eastern part of the Upper Rhine Graben (URG) is known as the "Hessisches Ried" (Fig. 1). This area has become an important research area for Quaternary graben development in recent years. According to VAN GiJSSEL (2006), the URG is a non-glaciated type region for mid Central European large and medium sized upland basins.

The historical landscape development in the late and post-glacial period in the northern URG was recently studied by Bos et al. (2008), DAmbeck (2005), Dambeck \& Bos (2002), DAmbeck \& Thiemeyer (2002) as well as ERKENs et al. (2009). The geometry of the Quaternary sediment body was investigated using high resolution reflection seismic by Haimberger et al. (2005) and Wirsing et al. (2007). The interaction between tectonics, and fluviatile and erosive processes, particularly along the western graben margin, was investigated by Peters \& VAN BALEN (2007a, b) as well as Peters et al. (2005). The sedimentological structure of the Pleistocene sedimentary fill in the northern Upper Rhine Graben has, however, not been looked at systematically in recent times. This was one of the reasons why the Geological Survey of Hessen (Hessisches Landesamt für Umwelt und Geologie (HLUG)) drilled several research boreholes in the Hessisches Ried in recent years. In addition to scientific aspects concerning the sedimentology, sedimentary petrography, vegetation history, palaeontology and tectonic development during the Pleistocene and Upper Pliocene, the investigation was also interested in applied geological aspects, which require a thorough understanding of the structure of the graben fill for their clarification. The focus of this aspect of the investigation was on hydrogeology, resource geology and geothermy.

The boreholes were designed to reveal the geometry of the Pleistocene sedimentary body in more detail, and to specify each of the facies in the area of investigation. The thickness of Quaternary sedimentary fill increases from the western to the eastern graben margin. There is also an increase in thickness from north to south-east in the direction of the Heidelberg Basin (Fig. 2). At the eastern graben margin of the Hessisches Ried, the fluviatile or limnic- 


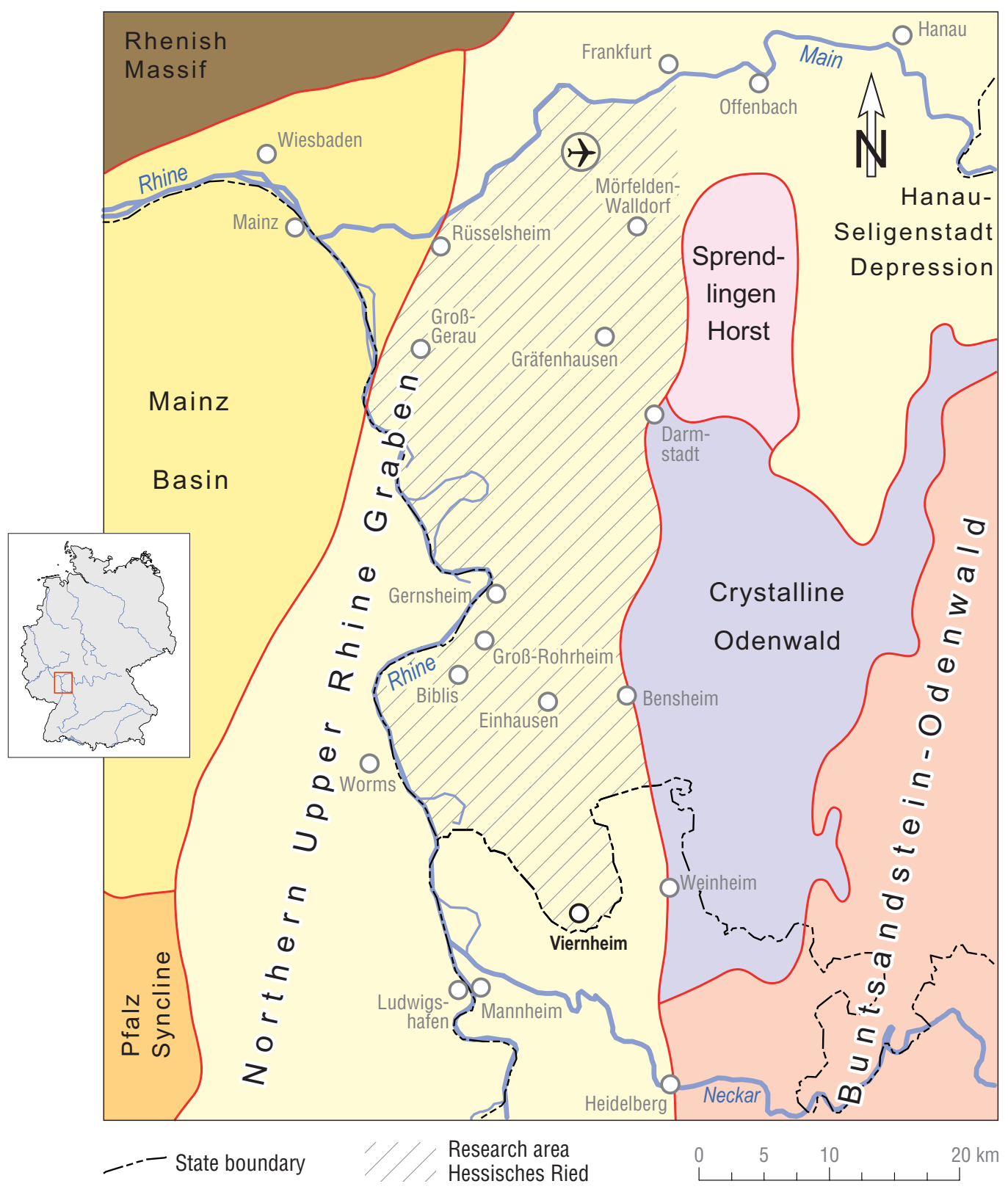

Fig. 1: Location map with the geological structural zones and the area of investigation "Hessisches Ried".

Abb. 1: Übersichtskarte mit den geologischen Strukturräumen und dem Untersuchungsgebiet „Hessisches Ried". 
fluviatile deposits repeatedly contain interbeds of redeposited sediments of hard rocks lying on higher ground further east, i.e., from the Odenwald or the Sprendlingen Horst. This hard rock, consisting of Palaeozoic crystalline rocks and sedimentary rocks of Rotliegend age (Sprendlingen Horst) and Buntsandstein, was intensively weathered during the Mesozoic and Tertiary. The resulting unconsolidated rock was easily eroded and redeposited during the Pleistocene periglacial periods. Directly along the graben margin in particular, there are also very high proportions of redeposited sediments derived from these source areas. The $111 \mathrm{~m}$ deep C/04 B1 borehole drilled south of Gräfenhausen north-west of Darmstadt (R 3472203 - H 5531111 based on the Gauss-Krüger coordinates of German topographic maps), clearly shows an almost $20 \mathrm{~m}$ thick sequence of redeposited sediments aligned east-west in this part of the northern URG, forming part of the Quaternary sedimentary sequence with a total thickness of $83.58 \mathrm{~m}$. These redeposited sediments can be traced for approx. $5 \mathrm{~km}$ from the graben margin in the northern URG. The Pleistocene fluviatile graben fill itself consists in the area of investigation of alternating fluviatile sands and gravels mixed up in various proportions, as well as silts, clays and peat. This sequence is the "Normal Facies" of the northern URG.

In the north part of the Hessisches Ried, the Rhenish sediments interfinger with the fluviatile sediments deposited by the Main river. Several hundred boreholes were geologically analysed and recorded by HLUG between 2003 and 2004 during the planning work for the Deutsche Bahn's ICE high speed rail track from Frankfurt/Main airport (Rhine-Main district) to Mannheim (Rhine/Neckar zone). This revealed the presence of fluviatile sediments, laid down by the Main all the way up to the area to the north of Gräfenhausen (borehole 2.3/41 drilled along the planned ICE track: R 3472332 - H 5533832). On the other hand, indisputable Rhenish sediments were also found as far north as the southern edge of Frankfurt airport. For instance, the borehole drilled close to the west runway (BK 1200; R $3465891-$ H 5542863) revealed Pleistocene, calcareous sediments of the Upper Rhine Graben beneath the Lower Pleistocene Untermain-Hauptterrassen Formation (Hoselmann 2007a). A research borehole drilled to the north of Mörfelden (R 3468725 - H 5538979) also penetrated Main and Rhine sediments. Limnic-fluviatile and fluviatile sediments of Pliocene age were penetrated below the base of the Quaternary at $64.5 \mathrm{~m}$ below ground level. The "Walldorf Horst" postulated by ANDERle \& Golwer (1980) with thin Quaternary sediments lying on unconsolidated Miocene sediment is therefore non-existent.

In the eastern part of the Hessisches Ried, the fluviatile sediments of the northern URG are overlain by a few metres of Weichselian aeolian sands, partially drifted to form dunes. The thickness of the aeolian sands can even exceed 30 metres in places, for instance, at the western edge of the town of Darmstadt. This means that the aeolian sands may also have been redeposited and incorporated in the normal facies of the Pleistocene graben fill. Sedimentation in the western part of the Hessisches Ried ended with Holocene fluviatile sediments laid down by various meander generations of the Rhine (DAMBECK 2005 amongst others).

The aim of the Viernheim research borehole was to derive a standard section for the "Normal Facies" of the graben fill in the northern URG, and to provide detailed descriptions of these sediments with regard to the sedimentology, sedimentary petrography, palaeobotany and palaeontology. It was also the intention to date these sediments by physical dating methods such as OSL, IR-RF, TIMS- ${ }^{230} \mathrm{Th} / \mathrm{U}$ and Burial Age Dating (DeHnert \& SCHLÜCHTER 2008; Preusser et al. 2008; Geyh 2008) and to provide information on sedimentation rates where possible. The form of subsidence in this region means that large parts of the section can be expected to be preserved in superposition.

The work on the Viernheim research borehole is closely related to other research activities in the Heidelberg Basin (Ellwanger et al. 2005). The first results of this work have already been published, particularly on the Ludwigshafen- 


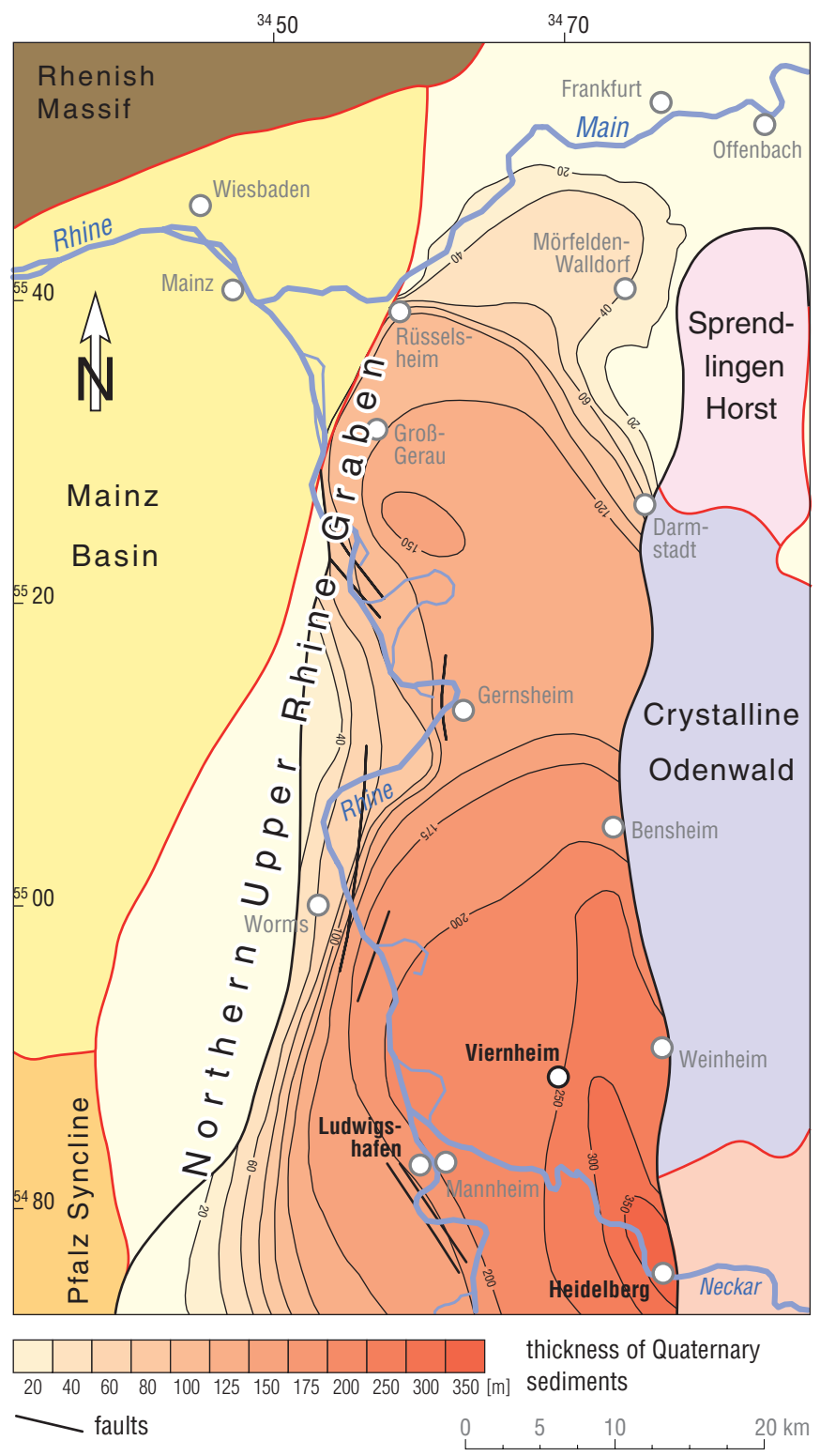

Fig. 2: Thicknesses of the Quaternary sediments in the northern URG; redrawn from BARTZ (1974), HAIMBERGER et al. (2005) as well as a great deal of new information from this work. The thickness of the Quaternary sediments increases from north to south as well as from west to east. The Heidelberg Basin begins in the Hessisches Ried south of Gernsheim. Around Heidelberg, a more strongly subsided subbasin revealing approx. $400 \mathrm{~m}$ of Quaternary sediments is documented.

Abb. 2: Mächtigkeitsverteilung quartärer Sedimente im nördlichen URG; umgezeichnet nach BARTZ (1974), HAIMBERger et al. (2005) sowie mit verschiedenen Aktualisierungen aus dieser Arbeit. Generell ist eine Zunahme quartärer Sedimente von Norden nach Süden sowie Westen nach Osten zu erkennen. Das Heidelberger Becken beginnt im Hessischen Ried südlich von Gernsheim und bildet bei Heidelberg ein noch stärker abgesenktes Teilbecken mit einer maximalen Quartärmächtigkeit von rund $400 \mathrm{~m}$. 
Parkinsel borehole. Of particular interest here is the work on sedimentary petrography (HAGEDORN 2004; HAGEDORN \& BoEnigk 2008), the fluviatile development during the Middle and Upper Pleistocene (WeIDENFELleR \& KÄRCHER 2008), palaeomagnetics (Rolf et al. 2008), palaeobotany (KNIPPING 2004, 2008; WEIDENFELLER \& KNIPPING 2008) and tectonics (Ellwanger et al. 2008).

\section{Geological description of the Viernheim research borehole}

\subsection{Viernheim research borehole}

The Viernheim research borehole lies almost $2 \mathrm{~km}$ to the north of Viernheim in the Hessisches State Forest, and specifically on the Buchnerschneise (R 3469080 - H 5492215; height of the borehole drilling location: $96.95 \mathrm{~m}$ asl; cf. point 5 in Fig. 10). The borehole was drilled by the drilling contractor Daldrup \& Söhne from January to June 2006. Down to the total depth (TD) of $350 \mathrm{~m}$, cores were cut in liners with an internal diameter of $10 \mathrm{~cm}$. The sediments penetrated by the borehole were ram cored to a depth of $40,5 \mathrm{~m}$. The wireline rotary coring method was then used to cut the next cores down to a depth of $64 \mathrm{~m}$. The cored section from $64 \mathrm{~m}$ to $228 \mathrm{~m}$ was again cut by ram coring. The wireline rotary coring method was again used from $228 \mathrm{~m}$ down to $350 \mathrm{~m}$ TD. Despite some technical problems during coring, the quality of the cores is very good with core recovery of approx. $97 \%$. The cores were sliced in halves: one half for scientific analysis and one half to be archived in the core store.

The borehole can be subdivided into two chronostratigraphic sections. From 350 m TD up to a depth of $225 \mathrm{~m}$, the section largely consists of fine-clastic sediments assigned to the Pliocene on the basis of their lithological character, composition, pedogenic overprinting, and supra-regional correlation. The section from $225-221.21 \mathrm{~m}$ is a transition zone between Pliocene and the Pleistocene. The overlying sequence largely consists of Pleistocene fluviatile sediments.

The discussion in the following dispenses with detailed core descriptions. This material can be requested from the author by e-mail, along with photo documentation and analysis data.

\subsection{Subdivision of the sedimentological record}

A strongly simplified description of the borehole section is shown in Figure 3. The Pliocene sequence can be subdivided as follows:

\begin{tabular}{|c|c|c|c|}
\hline Unit & $\begin{array}{l}\text { Depth in } \mathrm{m} \text { below } \\
\text { ground level }\end{array}$ & Description summary & Special aspects \\
\hline 10 & $225-228$ & $\begin{array}{l}\text { Fine-clastic cycle with numerous cal- } \\
\text { careous clusters; slightly oxidised in } \\
\text { the lower part, repeatedly strongly re- } \\
\text { duced at top }\end{array}$ & $\begin{array}{l}\text { Without strong pedo- } \\
\text { genic overprint }\end{array}$ \\
\hline $9 b$ & $228-228,6$ & $\begin{array}{l}\text { Strongly humic from here on, lignite } \\
\text { in part }\end{array}$ & \\
\hline $9 \mathrm{a}$ & $228.6-238.5$ & $\begin{array}{l}\text { Fine-clastic sediments, similar to unit } \\
7 \text {, dominantly reduced }\end{array}$ & $\begin{array}{l}\text { Without strong pedo- } \\
\text { genic overprint }\end{array}$ \\
\hline 8 & $238.5-250.45$ & $\begin{array}{l}\text { With fining-upward sequence starting } \\
\text { with gravely sand (together with unit } \\
\text { 9), repeated fine gravely horizons, silty } \\
\text { in the upper part; reduced in part }\end{array}$ & $\begin{array}{l}\text { With local sediment } \\
\text { source probably from } \\
\text { the Odenwald; sec- } \\
\text { tion damaged during } \\
\text { drilling }\end{array}$ \\
\hline
\end{tabular}




\begin{tabular}{|c|c|c|c|}
\hline Unit & $\begin{array}{l}\text { Depth in m below } \\
\text { ground level }\end{array}$ & Description summary & Special aspects \\
\hline 7 & $250.45-261$ & $\begin{array}{l}\text { Fine-clastic sediments, strongly spot- } \\
\text { ted: reduced and oxidised, calcareous in } \\
\text { clusters (similar to unit 1a, } 3 \text { and 5) }\end{array}$ & $\begin{array}{l}\text { Pedogenic overprint } \\
=\text { "Plinthosol" }\end{array}$ \\
\hline 6 & $261-270.44$ & $\begin{array}{l}\text { Sand-dominated unit with a silt horizon } \\
\text { at } 268-268.85 \mathrm{~m} \text {; largely reduced, also } \\
\text { oxidised zones }\end{array}$ & $\begin{array}{l}\text { Local sedimentary } \\
\text { source, probably from } \\
\text { the Odenwald }\end{array}$ \\
\hline 5 & $270.44-315.85$ & $\begin{array}{l}\text { Compact unit similar to } 1 \mathrm{a}, 3 \text { and } 7 \text {; } \\
\text { silts and clays, with repeated discord- } \\
\text { ant interbeds of sand, also calcareous } \\
\text { in clusters, predominantly strongly oxi- } \\
\text { dised and some reduced zones }\end{array}$ & $\begin{array}{l}\text { Strong pedo- } \\
\text { genic overprint = } \\
\text { "Plinthosol"; } \\
\text { Unit discordantly } \\
\text { overlain by } 6\end{array}$ \\
\hline 4 & $315.85-318.55$ & $\begin{array}{l}\text { Sand deposits, upper part reduced, silty } \\
\text { in part }\end{array}$ & $\begin{array}{l}\text { Local sediment } \\
\text { source, probably from } \\
\text { the Odenwald }\end{array}$ \\
\hline 3 & $318.55-323.1$ & $\begin{array}{l}\text { Similar to unit 1a, } 3,5 \text { and } 7 \text {, compact/ } \\
\text { homogenous }\end{array}$ & $\begin{array}{l}\text { Only weak pedogenic } \\
\text { overprint }\end{array}$ \\
\hline 2 & $323.1-330.62$ & $\begin{array}{l}\text { Sand-dominated unit, layered in part, at } \\
329-330 \text { m with fine-gravely clasts; hu- } \\
\text { mus in parts with redeposited lignite }\end{array}$ & $\begin{array}{l}\text { Local sediment } \\
\text { source, probably from } \\
\text { the Odenwald }\end{array}$ \\
\hline $1 b$ & $330.62-333.4$ & $\begin{array}{l}\text { Fine clastic, humus-banded, with sandy } \\
\text { horizons, with a lot of fine sand to- } \\
\text { wards the base, at the top similar to } 1 \mathrm{a}\end{array}$ & \\
\hline $1 \mathrm{a}$ & $333.4-350$ & $\begin{array}{l}\text { Fine-clastic sediments, strongly spot- } \\
\text { ted: reduced and oxidised, calcareous } \\
\text { in clusters }\end{array}$ & $\begin{array}{l}\text { Strong pedo- } \\
\text { genic overprinting = } \\
\text { "Plinthosol" }\end{array}$ \\
\hline
\end{tabular}

The Pliocene sediments are marked by a higher bedding density than the overlying sediments. The Pliocene sediments are followed discordantly by a short section which mainly consists of reworked Pliocene sediments. This zone is given a preliminary chronostratigraphic classification as Plio-Pleistocene - this section consists of:

\begin{tabular}{llll}
\hline Unit & $\begin{array}{l}\text { Depth in m below } \\
\text { ground level }\end{array}$ & Description summary & Special features \\
\hline 11 & $221.21-225$ & $\begin{array}{l}\text { Fining-upward sequence of } \\
\text { fine sand to silt, clayey, strong } \\
\text { humic concentrations in parts } \\
\text { in the upper section }\end{array}$ & $\begin{array}{l}\text { Transition zone with } \\
\text { numerous reworked Pliocene } \\
\text { sediments }\end{array}$ \\
\hline
\end{tabular}

This sequence is overlain by Pleistocene sediments. Up to $39.76 \mathrm{~m}$ below ground level, this sequence is divided into 10 cycles (I-X) which have similar internal structures that vary in thickness and with respect to other parameters. Generally the cycles are repeated sequences of fining-upward suites which begin discordantly with sandy-gravely sediments. Every sequence 


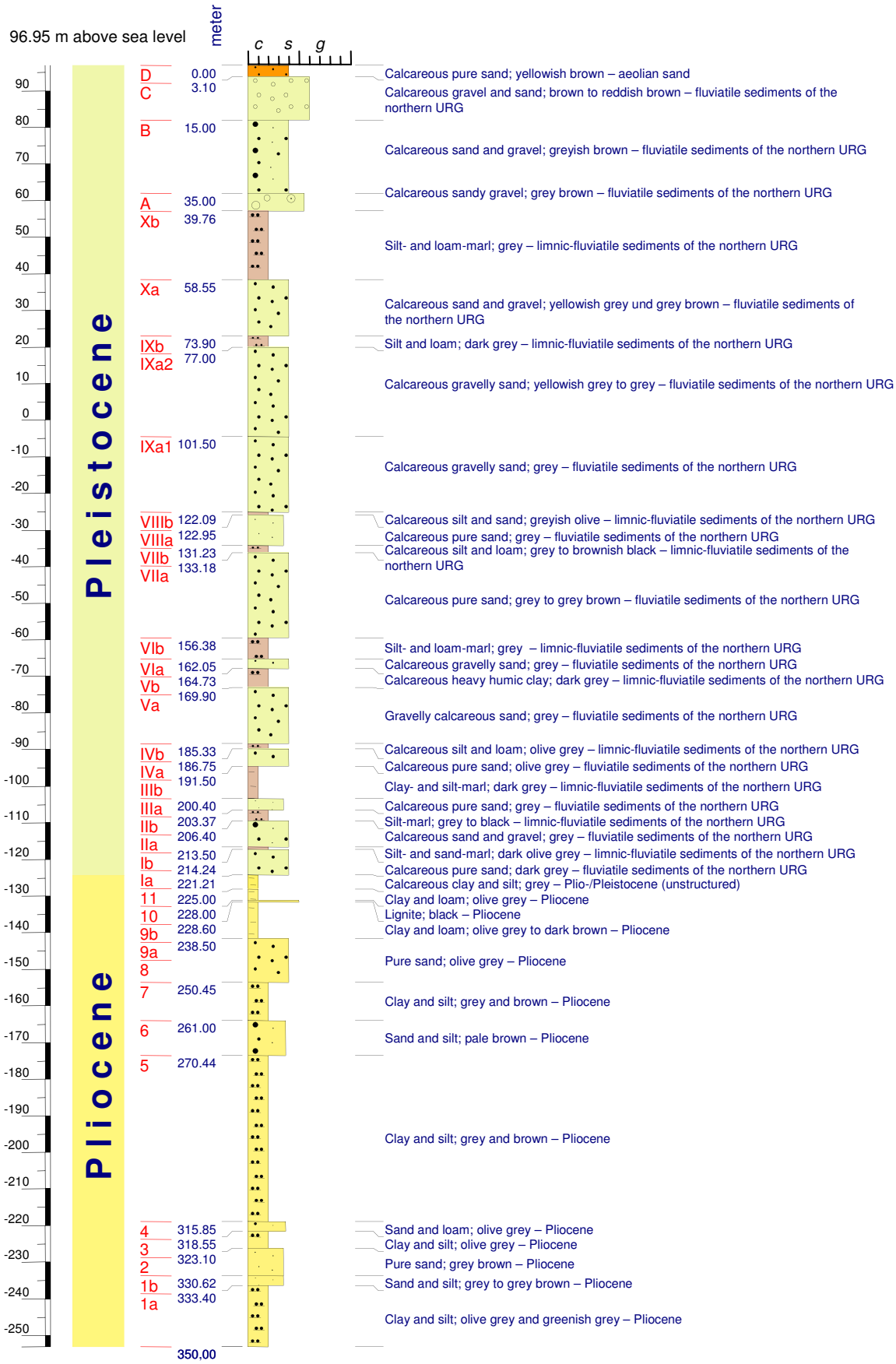

Fig. 3: Schematic geological section of the Viernheim research borehole showing a summary of the sedimentological units.

Abb. 3: Schematisiertes geologisches Profil der Forschungsbohrung Viernheim mit den zusammengefassten sedimentologischen Einheiten. 
Table 1: Summary of some characteristic sediments occurring in the area drilled by the Viernheim research borehole.

Tab. 1: Zusammenfassung einiger charakteristischer Sedimente, die im Gebiet der Forschungsbohrung Viernheim auftreten.

\begin{tabular}{ll}
\hline & characteristic features \\
\hline fluvial gravels and cobbles of the Rhine & $\begin{array}{l}\text { Quartz, quartzite, crystalline rock, lydite, } \\
\text { radiolarite }\end{array}$ \\
fluvial gravels and cobbles of the Neckar & $\begin{array}{l}\text { Muschelkalk and Late Jurassic limestone, } \\
\text { Buntsandstein sandstone, Keuper sandstone }\end{array}$ \\
Rhenish Facies & $\begin{array}{l}\text { well to very well sorted fine up to medium grained } \\
\text { sands, carbonate rich, greenish grey, light mica }\end{array}$ \\
\hline
\end{tabular}

ends with fine-clastic silts and clays. Other sequences can be identified within these cycles. The description repeatedly mentions sediments in "Rhenish Facies" (Table 1). This is a well to very well sorted grey to greenish-grey fine to medium grained sand. The carbonate content can exceed $20 \%$ in part.

A characteristic feature is the distinctive presence of mica. The light mica flakes can have diameters up to several millimetres.

This part of the well section has the following geological setup (cf. Figure 3):

\begin{tabular}{|c|c|c|c|}
\hline Section & $\begin{array}{l}\text { Depth in } \mathrm{m} \\
\text { below ground } \\
\text { level }\end{array}$ & Description summary & Special features \\
\hline $\mathrm{Xb}$ & $39.76-58.55$ & $\begin{array}{l}\text { Dominantly fine-clastic with sandy } \\
\text { intercalations, partially in Rhenish } \\
\text { Facies, at } 49 \text { and } 53.5 \mathrm{~m} \text { strongly humic, } \\
\text { five partial sequences in total, humic } \\
\text { clays and peat in the upper section }\end{array}$ & $\begin{array}{l}51.9-52.5 \mathrm{~m} \text { in typical } \\
\text { Rhenish Facies }\end{array}$ \\
\hline $\mathrm{Xa}$ & $58.55-73.9$ & $\begin{array}{l}\text { The cycle begins with sand and some } \\
\text { gravel, coarsening upwards, from } 67- \\
69 \mathrm{~m} \text { reddish because of the stronger } \\
\text { Neckar influence, then fluctuating fine } \\
\text { gravel portions }\end{array}$ & $\begin{array}{l}\text { Concretionary in part } \\
\text { due to calcareous } \\
\text { content }\end{array}$ \\
\hline $\mathrm{IXb}$ & $73.9-77$ & $\begin{array}{l}\text { Fine-clastic sediments, reduced at the } \\
\text { bottom, then humic up to } 75 \mathrm{~m} \text {, followed } \\
\text { by strong humic peat and finally by silt }\end{array}$ & $\begin{array}{l}70-80 \mathrm{~m}, 87.2-88.2 \\
\text { and } 101,8-103 \mathrm{~m} \text { in } \\
\text { typical Rhenish Facies }\end{array}$ \\
\hline IXa2 & $77-101.5$ & $\begin{array}{l}\text { Marked change in colour from grey to } \\
\text { more reddish colours up to } 98 \mathrm{~m} \\
\text { Coarsening-upward sequence, from } 88.2 \\
\text { m again sediments in Rhenish Facies, } \\
\text { becoming more fine-grained upwards }\end{array}$ & $\begin{array}{l}\text { Notable colour } \\
\text { change IXa2 to IXa1. } \\
\text { IXa2 with strong } \\
\text { influence from Neckar } \\
\text { sediments? }\end{array}$ \\
\hline IXa1 & $101.5-122.09$ & $\begin{array}{l}\text { VIIIb is discordantly overlain by sandy } \\
\text { zone with subordinate interbedded } \\
\text { gravely horizons }\end{array}$ & \\
\hline
\end{tabular}




\begin{tabular}{|c|c|c|c|}
\hline Section & $\begin{array}{l}\text { Depth in } \mathrm{m} \\
\text { below ground } \\
\text { level }\end{array}$ & Description summary & Special features \\
\hline VIIIb & $122.09-122.95$ & Thin fine sandy silts & $\begin{array}{l}\text { With calcareous } \\
\text { concretions and } \\
\text { geodes }\end{array}$ \\
\hline VIIIa & $122.95-131.23$ & $\begin{array}{l}\text { VIIb is erosively overlain by sands with } \\
\text { gravel grading into fine to medium- } \\
\text { sized sands towards the top, } 123-123.5 \\
\text { m oxidised, high concentrations of light } \\
\text { mica in part }\end{array}$ & $\begin{array}{l}124.5-126.5 \mathrm{~m} \text { in } \\
\text { typical Rhenish Facies }\end{array}$ \\
\hline VIIb & $131.23-133.18$ & $\begin{array}{l}\text { Fine clastic, reduced, more } \\
\text { humic towards the top with sandy } \\
\text { intercalations, oxidised in part }\end{array}$ & \\
\hline VIIa & $133.18-156.38$ & $\begin{array}{l}\text { VIb is erosively overlain by gravely } \\
\text { sands, becoming coarser upwards as } \\
\text { a coarsening-upward sequence, then } \\
\text { dominant sand with gravely horizons, } \\
\text { sand at the top }\end{array}$ & $\begin{array}{l}133.8-134 \mathrm{~m} \text { in typical } \\
\text { Rhenish Facies }\end{array}$ \\
\hline $\mathrm{VIb}$ & $156.38-162.05$ & $\begin{array}{l}\text { Fine clastic sediments with gravely } \\
\text { interbeds at } 161.1-161.45 \mathrm{~m} \text {, silt and clay } \\
\text { weakly reduced with oxidation zones } \\
\text { Vb is discordantly overlain by next }\end{array}$ & Characteristic banding \\
\hline VIa & $162.05-164.73$ & $\begin{array}{l}\text { fining-upward sequence starting with } \\
\text { gravely sands }\end{array}$ & \\
\hline $\mathrm{Vb}$ & 164.73-169.9 & $\begin{array}{l}\text { Fine clastic zone reduced at the bottom } \\
\text { and more humic towards the top, from } \\
168.2 \mathrm{~m} \text { reduced, in part oxidised, then } \\
\text { humic again }\end{array}$ & $\begin{array}{l}\text { Gravels largely from } \\
\text { the Neckar }\end{array}$ \\
\hline $\mathrm{Va}$ & $169.9-185.33$ & $\begin{array}{l}\text { IVb is erosively overlain by coarse } \\
\text { sands, gravely in part, very gravely } \\
\text { at } 182.5 \mathrm{~m} \text {, fluctuating gravel } \\
\text { concentrations in this section }\end{array}$ & $\begin{array}{l}169.9-172.5 \mathrm{~m} \text { in } \\
\text { typical Rhenish } \\
\text { Facies. Pedogenic } \\
\text { overprint in part }\end{array}$ \\
\hline $\mathrm{IVb}$ & $185.33-186.75$ & Silts and clays, partially reduced & Similar to IIIb \\
\hline IVa & $186.75-191.5$ & $\begin{array}{l}\text { IIIb is discordantly overlain by coarser } \\
\text { sands, grading into typical sands of the } \\
\text { Rhenish Facies }\end{array}$ & \\
\hline $\mathrm{IIIb}$ & $191.5-200.4$ & $\begin{array}{l}\text { Silts and clays, strongly humic in } \\
\text { part, light grey to dark greenish-grey } \\
\text { (reduced) }\end{array}$ & \\
\hline IIIa & 200.4-203.37 & $\begin{array}{l}\text { IIb is discordantly overlain by well } \\
\text { sorted, micaceous sands without gravely } \\
\text { horizons }\end{array}$ & $\begin{array}{l}\text { With typical Rhenish } \\
\text { Facies, fining upward } \\
\text { sequence overall }\end{array}$ \\
\hline
\end{tabular}




\begin{tabular}{|c|c|c|c|}
\hline Section & $\begin{array}{l}\text { Depth in } \mathrm{m} \\
\text { below ground } \\
\text { level }\end{array}$ & Description summary & Special features \\
\hline $\mathrm{IIb}$ & $203.37-206.4$ & $\begin{array}{l}\text { Fine-clastic sediments, humic in part, } \\
\text { also reduced }\end{array}$ & \\
\hline IIa & 206.4-213.5 & $\begin{array}{l}\text { Ib is discordantly overlain by sandy } \\
\text { gravel grading up into sand dominated } \\
\text { sediments, with abundant mica in parts }\end{array}$ & $\begin{array}{l}\text { Dominant limestones } \\
\text { in the gravel fraction }\end{array}$ \\
\hline $\mathrm{Ib}$ & $213.5-214.24$ & Mainly silts, reduced & \\
\hline Ia & $214.24-221.21$ & $\begin{array}{l}\text { Fining-upward sequence with gravely } \\
\text { sands and sands }\end{array}$ & $\begin{array}{l}\text { First sediments in } \\
\text { Rhenish Facies }\end{array}$ \\
\hline
\end{tabular}

This part of the section is overlain by a more coarse clastic carbonate unit more strongly of the sequence formed by Weichselian to Hoinfluenced by Neckar sediments (A to C), top

\begin{tabular}{|c|c|c|c|}
\hline Unit & $\begin{array}{l}\text { Depth in m below } \\
\text { ground level }\end{array}$ & Description summary & Special features \\
\hline $\mathrm{D}$ & $0-3.1$ & $\begin{array}{l}\text { Markedly coarse, pedogenically } \\
\text { overprinted aeolian sand }\end{array}$ & $0-1 \mathrm{~m}$ core loss \\
\hline $\mathrm{C}$ & $3.1-15$ & $\begin{array}{l}\text { Gravely sands and gravels with } \\
\text { fining-upward and coarsening-upward } \\
\text { sequences, Rhenish portion strongly } \\
\text { reduced }\end{array}$ & Neckar gravels \\
\hline B & $15-35$ & $\begin{array}{l}\text { Four fining-upward sequences, } \\
\text { inhomogeneous, } 27-32 \mathrm{~m} \text { gravel }\end{array}$ & $\begin{array}{l}\text { With Rhenish Facies } \\
\text { in the fine grained } \\
\text { parts, Neckar gravels }\end{array}$ \\
\hline A & $35-39.76$ & $\begin{array}{l}\mathrm{Xb} \text { is discordantly overlain by gravely } \\
\text { sands to gravels in three fining-upward } \\
\text { sequences }\end{array}$ & $\begin{array}{l}\text { With Rhenish Facies } \\
\text { in the fine grained } \\
\text { parts, Neckar gravel }\end{array}$ \\
\hline
\end{tabular}

The cycles I-X reveal fluviatile and limnic-fluviatile sediments which were mainly deposited by the Rhine. Mixing with Neckar sediments occurs in the gravely parts. Units A-C are, however, much more strongly dominated by gravel, and the influence of Rhenish sedimentation reduces upwards.

Gravel analysis was carried out at various depths to determine the provenance of the gravel (Table 2).

There are basically no significant changes in the gravel content. The values are similar to those for the area of the Neckar alluvial fans described by e.g. Löscher (1988). The fractions analysed are dominated by Keuper limestones and sandstones transported by the Neckar, as well as red sandstones from Buntsandstein areas. The interesting finding is that the limestones in the lowest sample in particular are partially dissolved. In addition to the Neckar pebbles, there is also mixing with a local component from the Odenwald. This is revealed by the relatively high proportion of red sandstones derived from the Buntsandstein, as well as crystalline pebbles. These are less well rounded, which indicates shorter transport distances. 
Table 2: Summary of the gravel analysis at various depths in the Viernheim research borehole. The figures are percentages and add up to $100 \%$ in total. 200 to 500 pieces of gravel were counted in the fraction higher than $5 \mathrm{~mm}$.

Tab. 2: Zusammengefasste Schotteranalysen aus verschiedenen Teufenbereichen der Forschungsbohrung Viernheim. Die Werte geben Prozent an und summieren sich insgesamt auf $100 \%$. Gezählt wurden zwischen 200 und 500 Kiese der Fraktion größer 5 mm.

\begin{tabular}{|c|c|c|c|c|c|c|c|c|c|}
\hline Layer & $\begin{array}{r}\text { Depth } \\
{[\mathrm{m}]} \\
\end{array}$ & quartz & crystalline & $\begin{array}{r}\text { red sandstone } \\
\text { (Buntsandstein) }\end{array}$ & $\begin{array}{r}\text { limestone } \\
\text { (Late } \\
\text { Jurassic) } \\
\end{array}$ & $\begin{array}{r}\text { limestone } \\
\text { (Muschelkalk) }\end{array}$ & lydite & $\begin{array}{r}\text { sandstone } \\
\text { (e.g. Keuper) } \\
\end{array}$ & $\begin{array}{r}\text { miscellaneous } \\
\text { (chert, } \\
\text { radiolarite, } \\
\text { phyllite, } \\
\text { claystone, } \\
\text { quartzite, and } \\
\text { marl) }\end{array}$ \\
\hline $\mathrm{C}$ & $\begin{array}{l}5.3- \\
5.75\end{array}$ & 20.5 & 22.5 & 8.5 & 17.0 & 17.2 & 1.6 & 6.7 & 6.0 \\
\hline B & $\begin{array}{r}31.7- \\
31.8\end{array}$ & 16.2 & 11.4 & 3.1 & 18.3 & 29.3 & 2.6 & 4.1 & 15.1 \\
\hline IXa2 & $\begin{array}{r}99- \\
99.5\end{array}$ & 6.5 & 15.9 & 19.4 & 26.4 & 13.9 & 2.0 & 9.0 & 7.0 \\
\hline VIIa & $\begin{array}{r}148.2- \\
148.5\end{array}$ & 26.6 & 10.5 & 12.2 & 16.7 & 20.7 & 1.1 & 9.6 & 2.5 \\
\hline VIb & $\begin{array}{r}161.3- \\
161.4\end{array}$ & 12.9 & 11.3 & 3.5 & 39.5 & 13.2 & 6.4 & 7.7 & 5.5 \\
\hline
\end{tabular}

The limestones are well to very well rounded because of their longer transport distances and lower hardness. The portions of up to $26.6 \%$ quartz, and lydite occurring as an accessory component, indicate mixing with Rhine pebbles. These were transported long distances from either the Black Forest or the Alps.

\section{Results}

\subsection{Heavy Mineral Analysis}

Various systematic investigations of the heavy mineral composition of Pliocene and Pleistocene sediments in the Upper Rhine Graben have been undertaken previously (e.g. VAN Andel 1950; Maus in Bartz 1982; Boenigk 1987; Hagedorn 2004; Hagedorn \& Boenigk 2008). Heavy mineral analysis is an important instrument for characterising fluviatile Pliocene and Pleistocene fine sands from the Rhine system as part of work conducted in the middle Rhine area, the Lower Rhine Embayment and the Netherlands. The composition of the heavy mineral distribution provides information on the source of the sediments as well as the weathering of the sediments.

171 samples from the Viernheim research borehole were analysed for their heavy mineral content. The main analytical method was that of BoenigK (1983). Sodium polywolframate $\left(\mathrm{Na}_{6}\left(\mathrm{H}_{2} \mathrm{~W}_{12} \mathrm{O}_{40}\right) * \mathrm{H}_{2} \mathrm{O}\right)$ with a density of $2.85 \mathrm{~g} /$ $\mathrm{cm}^{3}$ was used as the heavy liquid to separate the heavy from the light fraction in a centrifuge. The samples were boiled with concentrated hydrochloric acid prior to centrifuging to remove iron and manganese hydroxide crusts which would complicate the identification. The disadvantage of this method is the dissolution of carbonate, apatite and parts of monazite and olivine (Boenigk 1983). This was deemed acceptable because of the benefit of being able to make comparisons with our own and other previous analyses.

Generally, the sediments in the borehole from a depth of 350 to $225 \mathrm{~m}$ are dominated by the stable heavy mineral group (Fig. 4). These are mainly zircon, but also tourmaline and rutile. 


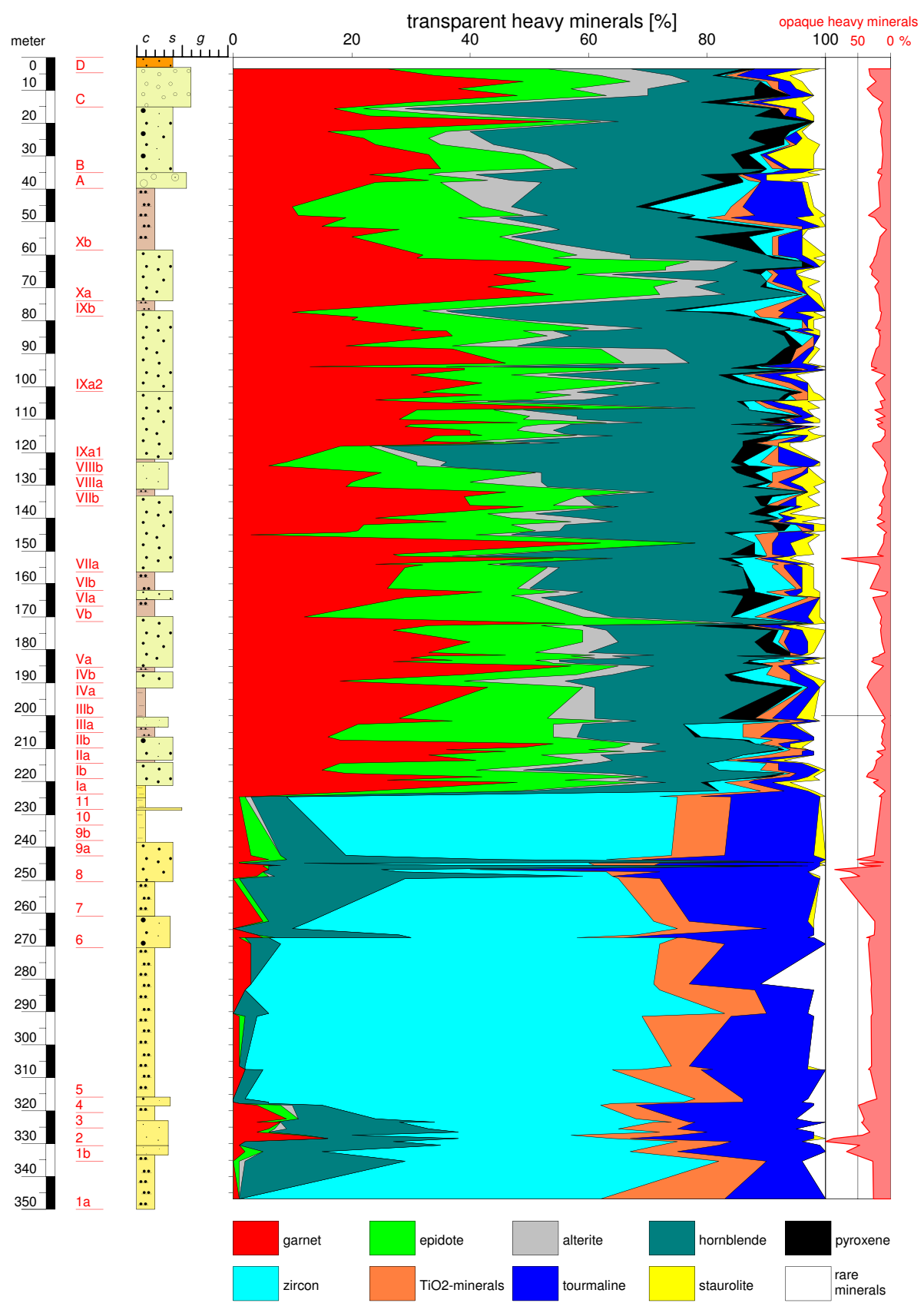

Fig. 4: Heavy mineral diagram on 171 sand samples from the Viernheim research borehole; hornblende includes green and subordinate brown hornblende; the $\mathrm{TiO}_{2}$-group includes rutile, brookite and anatase; the rare minerals include andalusite, sillimanite, disthene, titanite, monazite and spinel.

Abb. 4: Schwermineraldiagramm an 171 Sandproben der Forschungsbohrung Viernheim; Hornblende beinhaltet grüne und untergeordnet braune Hornblende; die $\mathrm{TiO}_{2}$-Gruppe schließt Rutil, Brookit und Anatas ein; die seltenen Minerale fassen Andalusit, Sillimanit, Disthen, Titanit, Monazit und Spinell zusammen. 
Subordinately also occur heavy minerals of the Rhine Group (garnet, green hornblende and epidote) (cf. also Fig. 5). However, some samples have very high percentages of dark green hornblende (up to $86 \%$ ).

The composition of the heavy mineral spectrum changes significantly above sample 222,9-222,8 m: zircon, the $\mathrm{TiO}_{2}$-group and tourmaline become insignificant. These are replaced by garnet, epidote and green hornblende which determine the composition of the heavy minerals in the sand fraction, although the distribution overall remains relatively homogenous. This is emphasised even more when the heavy minerals are divided into separate groups (Fig. 5). The Rhine Group dominates with proportions between 60 and $80 \%$. Instable minerals have sometimes undergone strong alteration or are strongly dissolved. Garnet shows some evidence of corrosion, and green hornblende has been strongly altered in parts. Accessory minerals include the volcanic heavy minerals pyroxene and brown hornblende.

Boiling with concentrated $\mathrm{HCl}$ leads to the dissolution of some heavy minerals such as carbonate and apatite. A test run with 16 samples studied at the effect of the concentrated $\mathrm{HCl}$ treatment on the heavy mineral distribution. Figure 6 shows the distribution of selected samples with and without $\mathrm{HCl}$ treatment. Generally, the heavy mineral distribution remains the same with or without treatment. The differences lie within the range of statistical error. However, there is a significant rise in opaque heavy minerals (no $\mathrm{HCl}$ boiling), that is explained by the iron and manganese hydroxide encrustations on some grains which can therefore not be identified in transmitted light under a polarised microscope. Apatite now occurs in proportions up to $8 \%$, however, only in samples between 163.55 and $5.5 \mathrm{~m}$. In general, counting during heavy mineral analysis becomes much more difficult, and some grains can only be identified after a lot of work. The difference for the sediments in the Upper Rhine Graben is, however, not as significant because of the presence of carbonate-rich sands which have not been subject to any very intensive weathering processes after sedimentation (cf. Chapter 3.2). Heavy mineral analysis without boiling with $\mathrm{HCl}$ is very difficult in the noncalcareous Pleistocene terrace deposits with no overburden to protect them from weathering, which are characterised by strong iron and manganese hydroxide deposits, and are frequent in the Middle Rhine and Lower Rhine areas. This can give rise to erroneous results. Decisions to change the methodology should therefore be looked at very critically because changing the methodology would considerably restrict direct comparison with most of the old analysis data collected in the Rhine area.

\subsection{Analysis of the Carbonate Content}

The carbonate content was analysed in 136 sand samples from the Viernheim research borehole. The samples were initially ground up in a mortar before being ground down to ca. $100 \mu$ in a ball mill. The carbonate content was determined using the method described by Scheibler (DIN ISO 10693), which involved two to three measurements. The results were used to derive an average number. Total carbonate content was determined in each case. The carbonate in sediments from the Upper Rhine Graben primarily consists of calcite $\left(\mathrm{CaCO}_{3}\right)$, and to a lesser extent also dolomite $\left(\mathrm{CaMg}\left(\mathrm{CO}_{3}\right)_{2}\right)$.

The analysed sediments are almost all calcareous above the boundary at $225 \mathrm{~m}$. Concentrations fluctuate significantly between 0.96 and $37.17 \%$ (Fig. 7). The sediments in the lower sequences are almost completely non-calcareous. A notable finding is that the carbonate concentration in the Viernheim research borehole fluctuates very strongly in general. A similar carbonate distribution picture was also shown in sediments from the borehole drilled less than $1 \mathrm{~km}$ to the south down to a TD of 110 $\mathrm{m}$ to investigate the groundwater (STW Viernheim; R 3469366 - H 5491377; point 4 in Fig. 10). The carbonate concentration in 26 samples ranges from 0,02 to $26.85 \%$. The highest carbonate values are found in the fine clastic sediments (fine sands) predominantly in the 


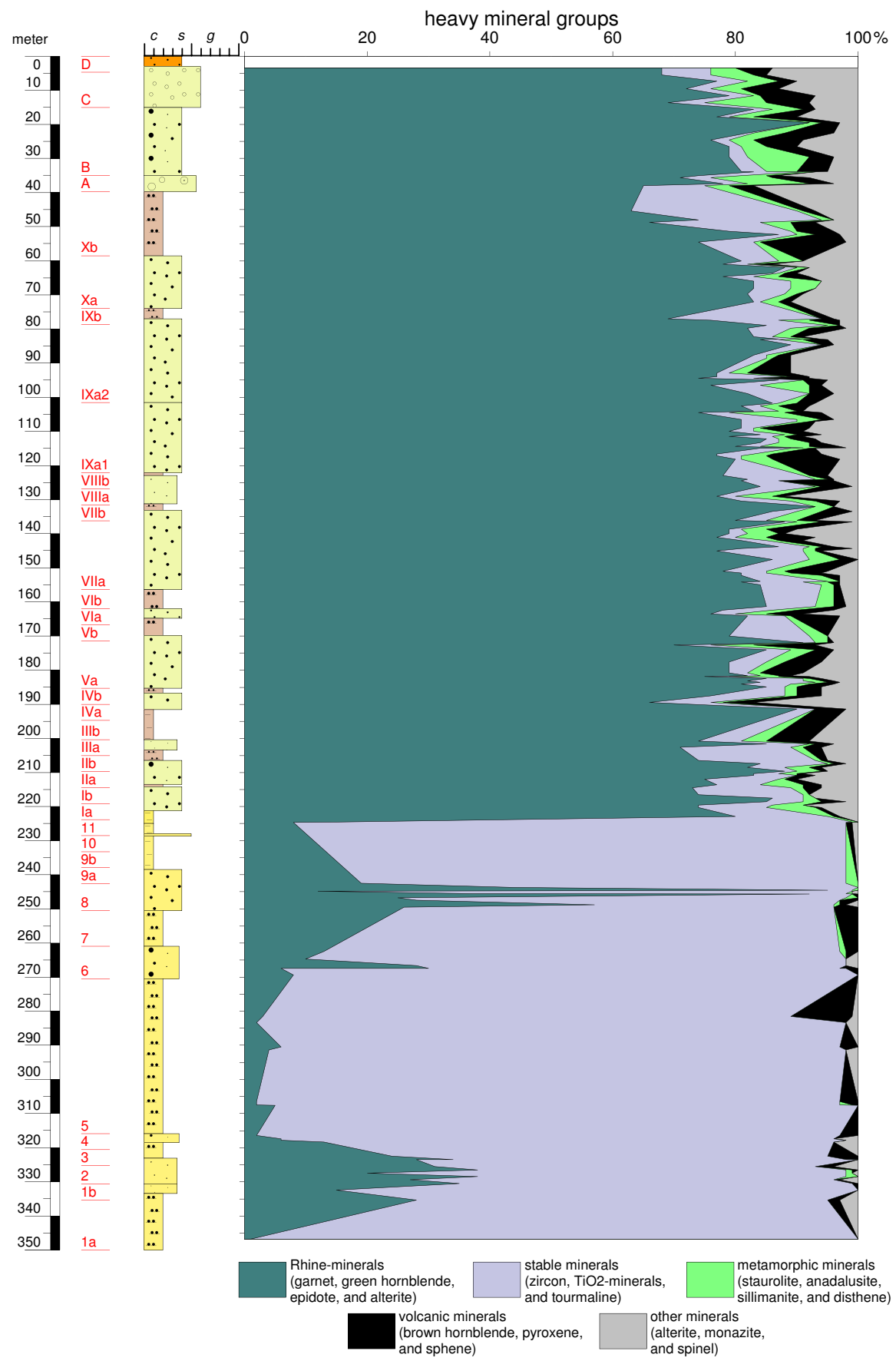

Fig. 5: Heavy mineral distribution divided into heavy mineral groups (after VAN ANDEL 1950 and VINKEN 1959), used for provenance analysis.

Abb. 5: Verteilung der Schwerminerale nach Schwermineralgruppen (nach VAN ANDEL 1950 und VINKEN 1959), die zur Liefergebietsanalyse verwendet wurden. 


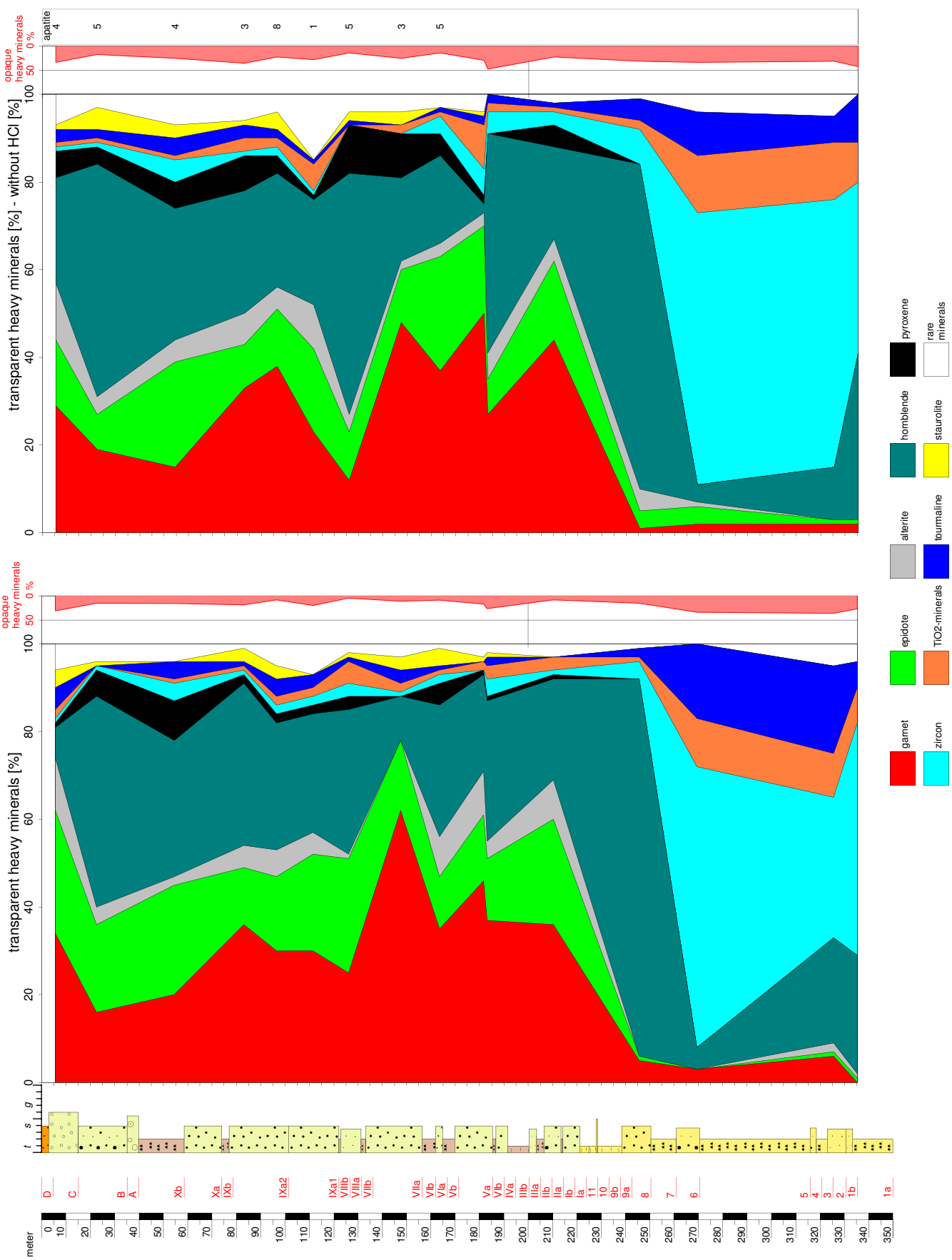

Fig. 6: Heavy mineral distribution in 16 selected samples from the Viernheim research borehole with and without $\mathrm{HCl}$ treatment. Apatite was counted separately in the samples prepared without boiling in $\mathrm{HCl}$.

Abb. 6: Schwermineralverteilung von 16 ausgewählten Proben der Forschungsbohrung Viernheim mit und ohne Behandlung durch $\mathrm{HCl}$. Bei der Probenaufbereitung ohne Kochen mit HCL wurden Apatite separat mitgezählt. 
carbonate content/unstable heavy minerals

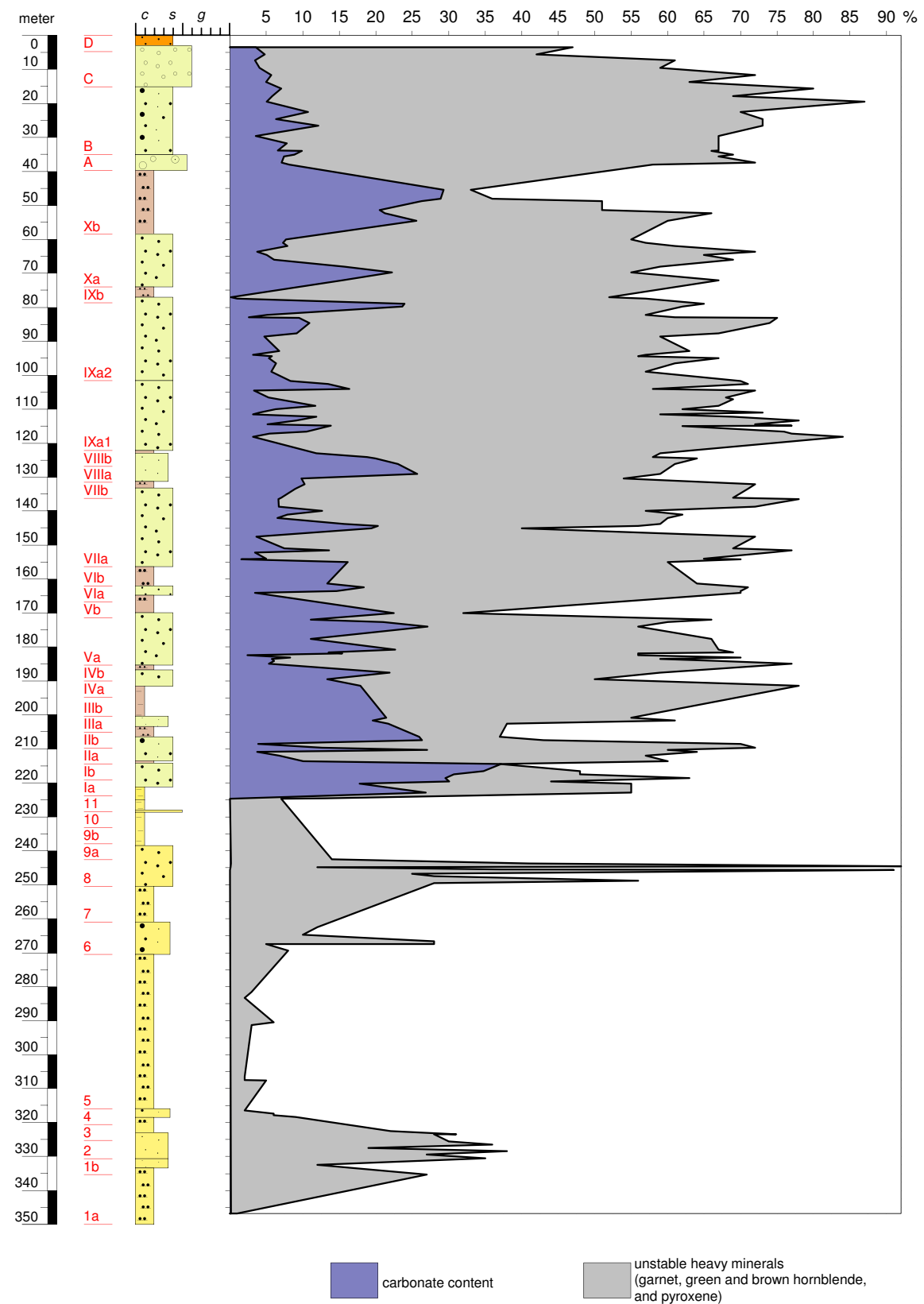

Fig. 7: Carbonate distribution from 136 sand samples from the Viernheim research borehole. The carbonate content is shown in relation to the group of unstable heavy minerals which weather easily in post-sedimentary environments.

Abb. 7: Carbonatverteilung von 136 Sandproben der Forschungsbohrung Viernheim. Der Carbonatgehalt wurde in Bezug zur Gruppe der instabilen Schwerminerale gesetzt, die postsedimentär leicht verwittern. 
Rhenish Facies, as in the Viernheim research borehole. A similar picture is shown by another research borehole (C/00-BK01), lying between Biblis and Groß-Rohrheim (Fig. 1), approx. 18 $\mathrm{km}$ north-west of the Viernheim research borehole (R 3460250 - H 5508325). The Quaternary base lies almost $100 \mathrm{~m}$ below ground level. The carbonate concentrations in the 42 samples fluctuate between 1.39 and $22.71 \%$. They are therefore lower in general than the boreholes further to the south. However, the C/00-BK01 research borehole does not have the silty and clayey beds with fine sand intercalations which usually contain the calcareous sediments. Future work should investigate whether the distribution pattern of the carbonate concentrations can be correlated between boreholes.

\section{Discussion}

\section{Subdivision of the Viernheim research borehole}

The Viernheim research borehole can be divided into four sections (cf. Chapter 2). The zone from 350 to $225 \mathrm{~m}$ contains clay-rich, densely layered limnic-fluviatile deposits laid down on a floodplain. Some of these deposits have been subjected to strong post-sedimentary pedogenic overprinting giving rise to soils similar to plinthosols. These soils were formed by stagnant water or under the influence of groundwater, and have gley and pseudo-gley characteristics. Rust and bleach spots are typical of plinthosols. They are formed under humid-tropical climatic conditions. The fine clastic sediments contain calcareous clusters at some places and repeated intercalations of sandy deposits. Sections 8 to 9 (Fig. 3) comprise a fining-upward sequence topped by an organic sediment (lignite). The sands have partly high proportions of green hornblende indicating a local sedimentary source from the Odenwald situated to the east (Fig. 8). The extreme dominance of such an unstable mineral group (up to $86 \%$ ) must indicate the local provenance of the mineral because it would otherwise have become much more intensively mixed with extremely stable heavy minerals. Amphiboles formed by magmatic crystallisation or by metasomatic processes are typical for the crystalline Odenwald geology. In the other cases, the heavy mineral spectrum is characterised by high percentages of stable minerals such as the dominant zircons, but also tourmaline and the $\mathrm{TiO}_{2}$-group. The Black Forest and the Vosges are interpreted as the sources of the subordinate proportions of garnet and epidote (HAGEDORN \& Boenigk 2008). Sections 1 to 10 (Fig. 3) of the well section are classified as Pliocene.

The next section (Section 11) is a transition zone which follows discordantly from 225 to $221.21 \mathrm{~m}$ and is interpreted as a reworked horizon. This section contains deposits derived from the underlying sediments which have been significantly reworked. In terms of heavy minerals, it contains a rather localised stable spectrum as well as a typical Pleistocene spectrum dominated by the Rhine Group. This section is preliminarily classified as Pliocene to Pleistocene.

The zone from 221.21 to $39.76 \mathrm{~m}$ in the Viernheim research borehole is made up of ten basically repeated suites (I-X) which begin autocyclically and discordantly with gravely sands and end with clayey sediments or peat. The thickness of each cycle fluctuates between $6.17 \mathrm{~m}$ (IV) and $48.19 \mathrm{~m}$ (IX). Additional partial sequences were identified in each cycle. The sediments (I-X) are almost exclusively medium to strongly calcareous. A typical feature is the repeated occurrence of very well sorted sands of the "Rhenish Facies" (cf. Chapter 2.2). These were formed by fluviatile flood sediments from the Rhine. The whole section in the well contains sediments dominated by the Rhenish Facies, with a gravel fraction which includes pebbles from the Neckar, and subordinately local components with crystalline pebbles from the Odenwald and red sandstones from the Buntsandstein. However, high percentages of quartz and the presence of lydite also show that the gravel fraction contains material sourced from areas to the south of the Neckar (Tab. 1 and 2).

The fluviatile part of the section is topped from 39.76 to $3.1 \mathrm{~m}$ by highly gravely sands and 


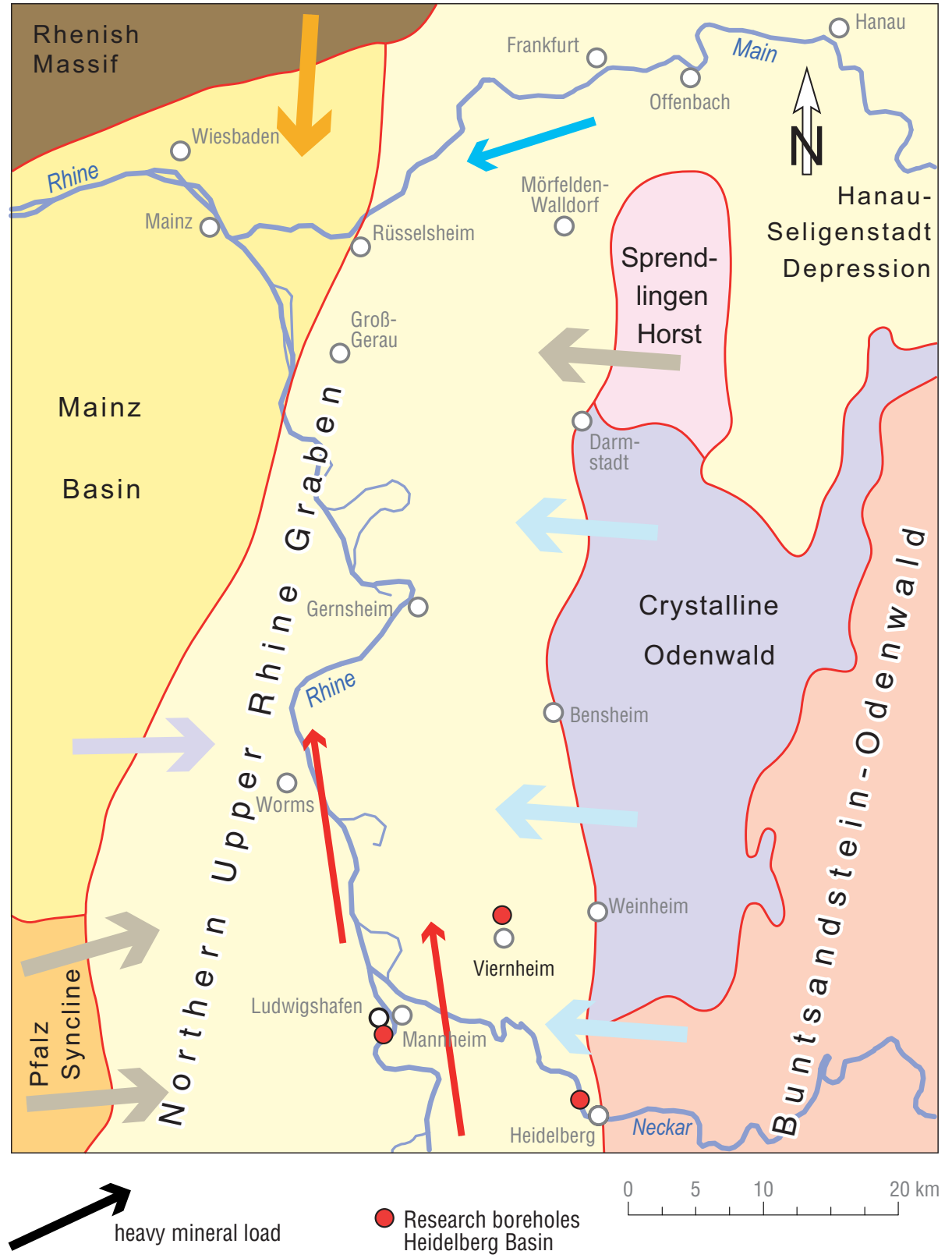

Fig. 8: Heavy mineral deposits during the Pliocene in the northern Upper Rhine Graben. Dominated by locally reworked sediments with stable heavy minerals and subordinate unstable heavy minerals derived from the Black Forest and the Vosges. Repeated local deposition from the graben margins which dominantly supply green hornblende in the eastern part of the northern URG.

Abb. 8: Schwermineralschüttungen während des Pliozäns im nördlichen Oberrheingraben. Dominant sind lokal aufgearbeitete Sedimente mit stabilen Schwermineralen und untergeordnet instabilen Schwermineralen, die aus dem Schwarzwald und Vogesen stammen. Wiederholt kommt es zu lokalen Schüttungen von den Grabenrändern, die im östlichen Teil des nördlichen URG dominant grüne Hornblende liefern. 
gravels mainly laid down by the Neckar. The dominance of the Rhine Group in the heavy mineral fractions in the sands, however, indicates mixing with Rhenish sediments around Viernheim. This is also indicated by the quartz constituents and lydite in the gravel fraction (Tab. 2). This section is also marked by dominant fining-upward and subordinately coarsening-upward sequences. The top of the section from $3.1 \mathrm{~m}$ to the ground surface is formed by Weichselian to Holocene aeolian sands.

The unequivocal identification of the Rhine signal in the heavy mineral fraction of the sands can be deduced from the proportions of heavy minerals in the sediments. Unlike the Pleistocene Neckar sediments which only contain around $0.04 \%$ heavy minerals, the Rhine sediments contain approx. $0.5 \%$ heavy minerals. This means that the fluviatile Rhenish sediments have around 10 times more heavy minerals than the Neckar sediments (Fig. 9). HAGEDORN (2004) reports similar findings. The change in provenance in sample $222.8 \mathrm{~m}$ show a strongly alpidic dominated heavy mineral spectrum, indicating the connection of the Rhine to the Alpine drainage system. The general homogenous structure of the heavy mineral distribution (Fig. 4 and 5) in the Pleistocene shows that lateral sources of sediment in the Viernheim area are almost completely absent. This locality is therefore different to that of the Ludwigshafen-Parkinsel borehole, for instance, which is marked by the periodic deposition of local sediments from the western graben margin (HAGEDORN \& BoENIGK 2008).

This confirms the assumption by HAGEDORN \& Boenigk (2008), that the Rhine tended to flow in the eastern part of the northern URG during the Pleistocene. Subordinate proportions of volcanic heavy minerals (pyroxene and brown hornblende) are probably not associated with the initiation of Middle Pleistocene East Eifel volcanism prior to approx. $700 \mathrm{ka}$ (BOGAARD \& SCHMINCKe 1990). In principle, the Neckar could also be the source for the pyroxenes as well as the brown hornblendes, although a strong decrease in the pyroxenes is observed towards its confluence with the Rhine as a result of dissolution and dilution by tributaries (VAn Andel 1950).

The importance of heavy mineral analysis for provenance analysis in the northern Upper Rhine Graben is highlighted by a comparison of the unstable heavy minerals (garnet, green and brown hornblende, and pyroxene) with the carbonate content (Fig. 7). The post-sedimentary weathering of sediments with a pedogenic overprint initially gives rise to a decrease in and relocation of the carbonate content. If the section has also undergone pedogenic overprinting, which was not obvious in the section, this would also have led to a decrease in the concentration of unstable heavy minerals. However, this is not the case in the Viernheim research borehole because zones with lower carbonate contents for instance have raised levels of unstable heavy minerals. No correlation is shown between low carbonate contents and low concentrations of unstable heavy minerals. This in turn means that the Pleistocene sediments have almost preserved their original heavy mineral association and are therefore ideal for provenance analysis. Some of the samples show signs of dissolution and traces of corrosion.

\section{Stratigraphy}

The lithostratigraphic subdivision of the Viernheim research borehole is proving difficult at the current state of the investigation because of the general absence of reliable data. The initial correlations can only be undertaken on the basis of analogies with other boreholes in the area, in the Lower Rhine Embayment (LRE), and in The Netherlands (detailed investigations in the Dutch/German border by e.g. DonDERS et al. 2007; Kemna \& Westerhoff 2007; Westerhoff et al. 2008). The most distinct lithological changes in the borehole are at $225 \mathrm{~m}$, and after the thin reworked horizon at $221.21 \mathrm{~m}$. The change at $225 \mathrm{~m}$ is considered to be the boundary between the Pliocene and the Pleistocene. The Plio-Pleistocene boundary at $2.58 \mathrm{Ma}$ is used in the sense of BowEN \& GIBBARD (2007), GibBARD \& CoHEN (2008), LitT 

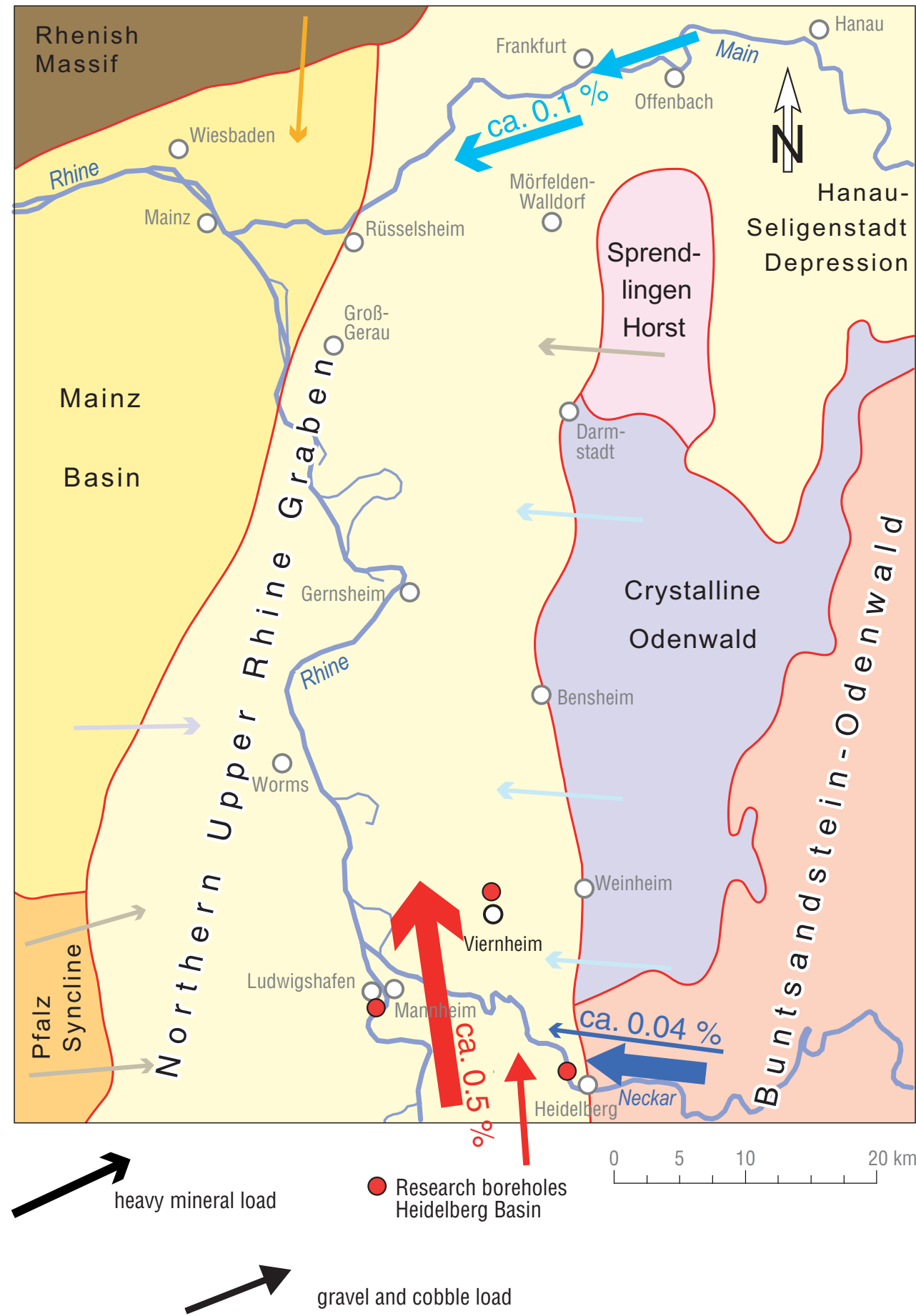

Fig. 9: Heavy mineral and gravel deposition during the Pleistocene in the northern Upper Rhine Graben.

Abb. 9: Schwermineral- und Kiesschüttungen während des Pleistozäns im nördlichen Oberrheingraben. 
(2007), and Preusser (2008) and coincide with the palaeomagnetic Gauss/Matuyama boundary. The deposition of Rhine Group alpine heavy minerals in the URG already is of Late Pliocene age (Hagedorn \& Boenigk 2008; Preusser 2008). Investigations in the LRE confirm this: a first shift from a stable heavy mineral spectra to unstable spectra of alpine type was detected in the Kieseloolite Formation (Kemna 2005, 2008 a, b). The Öbel beds (Latest Pliocene) also contain unstable heavy mineral spectra (BOENIGK \& FRECHEN 2006; Donders et al.2007; KEMNA \& WeSTERHOFF 2007). In some parts of the LRE the Öbel beds cover the Reuver Clay s.s. and thus define the top of the Pliocene sedimentation. In the Viernheim research borehole, no typical alpine heavy mineral spectra can be found below a depth of $225 \mathrm{~m}$. Consequently, these sediments are correlated with the Pliocene. A larger unconformity at this depth must be accepted. There is no doubt that a marked change in sedimentation took place at that time. At the present stage of the investigation a further stratigraphic subdivision of these Pliocene sediments is not possible. This characteristic change at $225 \mathrm{~m}$ in the Viernheim research borehole is comparable to the boundary at $176 \mathrm{~m}$ in borehole $\mathrm{P} 34$ Ludwigs-hafen-Parkinsel (WeIDENFELler \& KÄrCher 2008; Weidenfeller \& KNIPPING 2008). There are also indications in the P 34 borehole of a palaeomagnetic change from the Gauss to Matuyama-Chron (Rolf et al. 2008). RoLF et al. also proposed that a characteristic change of the magneto-minerals from goethite (Pliocene) to greigite (Pleistocene) can be interpreted as a climatic signal. Pollen analysis from organic sediments just beneath and above the boundary at $225 \mathrm{~m}$ are planned to provide important information on the age of this section in the Viernheim research borehole.

Another key zone in the borehole is the $\mathrm{Xb}$ section (58.55 to $39.76 \mathrm{~m}$ ). According to the hydrostratigraphic classification, this uppermost significant fine-clastic section of the borehole corresponds to a high resolution Obere Zwischenhorizont $(\mathrm{OZH})$ in the sense of the hydrogeological mapping in the Rhine/Neckar zone (HGK 1999) or the sequence-stratigraphic equivalent to the Ladenburg Horizon (Symbolschlüssel Geologie Baden-Württemberg 2007, Villinger 2005). This section has been classified as part of the Cromerian Complex since ENGESSER \& MüNZING (1991) on the basis of its mollusc fauna. Palynological investigations by KNIPPING $(2004,2008)$ on various sections in the Mannheim-Ludwigshafen area led to the conclusion that the OZH contains several interglacial flora which are assigned to the Cromerian Complex. A correlation with the Eemian interglacial is ruled out. This means that Section $\mathrm{Xb}$ in the Viernheim borehole can also be assumed to be of Cromerian age. Important biostratigraphic indications of the Lower Pleistocene sections in particular are provided by the investigations conducted by WedEL (2008). No other chronostratigraphic interpretations of the Viernheim research borehole are possible at the current stage of the research.

\section{Regional Trends}

Regional trends can only be investigated at on the basis of characteristic horizons or boundaries which extend over larger areas. The horizons selected for this purpose are the Quaternary base as well as the top and base of Section $\mathrm{Xb}$. This of course presupposes that the same unit or boundary could be selected for the correlation in the various wells and correlation could only use those boreholes with reliable stratigraphic logs, and gamma logs where possible (Tab. 3 and Fig. 10). Despite a large number of boreholes in the Hessisch part of the area of investigation, only eight boreholes in the Viernheim-Bensheim area are currently suitable for such a correlation.

The top of Section $\mathrm{Xb}$ dips to the south towards the centre of subsidence of the Heidelberg Ba$\sin$. The thickness of the unit increases accordingly. The minor amount of data available on the Quaternary base indicates a similar picture with a major increase in thickness from north to SSE. Care must be taken for the difference in the quality of the samples. The absence of Section $\mathrm{Xb}$ in the Einhausen research borehole highlights a fundamental problem when look- 
ing at the Pleistocene sedimentary fill in the northern Upper Rhine Graben: some horizons are very difficult to correlate, particularly towards the north. Despite high subsidence rates in this part of the northern URG as well, horizons are absent and can no longer be lithologically correlated even over short distances. Although correlation seems to function reasonably well in the centre of the Heidelberg Basin, there are also some fine-clastic horizons here which are only of restricted use for lithostratigraphic correlations. For instance, a fine-clastic horizon occurs in the Deponie Hirschländer borehole GWM1/03 at a depth of 21.58 to $25.65 \mathrm{~m}$ (thickness $4.07 \mathrm{~m}$ ). This horizon is not seen in any of the surrounding boreholes. This is interpreted as indicating the presence of a very local channel deposit cut into the older sediments. Although easier to correlate regionally, the flood deposits of Section Xb become thinner as the distance from its subsidence centre increases, and even disappear in some cases. The conclusion drawn from this is that the use of sequence-stratigraphic models - as used for instance by LANG (2007) for the Hanau-Seligenstadt Basin (Fig. 1), a parallel structure to the URG - are more promising. Determining the $\mathrm{A} / \mathrm{S}$ rates $(\mathrm{A}=$ accommodation space available for the sediment; S: sediment supply), and the interpretation of $\mathrm{A} / \mathrm{S}$ domains can be used successfully in sedimentary basins with low subsidence rates. This approach needs to be tested first in sedimentary basins with higher subsidence rates, such as the northern URG.

\section{Comments on supra-regional correlation and outlook}

The Rhine as the link between the Alpine and North European glaciated areas also linked up different areas of provenance, accumulation areas and tectonic structural areas during the Quaternary (Preusser 2008; Westerhoff 2008). The typical sediments of the Rhenish Facies which are wide-spread in the northern Upper Rhine Graben also have equivalents downstream. At the northern edge of the URG in Wiesbaden (Fig. 1), deposits called the Mosbach Sands occur which have supraregional significance because of their rich and typical fossil content (BoENIGK 1977/78; KAHLKe 2007; Keller 1999). In particular, the Graues Mosbach Horizon (nowadays called the Haupt-Mosbach-Subformation, HoselmanN 2007b) assigned to the Cromerian Complex, has significant macroscopic and sedimentary petrographic similarity with the Rhenish Facies in the Heidelberg Basin in the URG. The lower Middle Rhine zone contains the Hönningen Sands in the Mittelrhein-Hauptterassen Formation (WeIDENFELLER 2007), which is almost identical to the Rhenish Facies in the URG (BIBus 1980; Boenigk \& Frechen 2006; Boenigk \& Hoselmann 1991; Hoselmann 1996). The Rhine Group dominates the heavy mineralogy in these sediments, and carbonate contents of almost $30 \%$ have been measured. These sediments are probably part of the Cromerian Complex. Similar sediments also occur in the upper Middle Rhine (Bibus \& Semmel 1977). No other correlatable sediments are known in the other terraces of the Middle Rhine or in the Lower Rhine Embayment. The question therefore remains whether the sediments either did not accumulate in other times or whether they did not survive because they are easy to erode. In the area of the lower Middle Rhine, fluviatile terrace sediments occur in a series of terraces so that the uplift of the Rhenish Massif exposed the sediments to much stronger postsedimentary erosion than the deposits in the Heidelberg Basin.

A more detailed explanation is required in the future of the type of mechanism which controlled the depositional cycles. A key role is played here by the uplift of the German Mittelgebirge and the subsidence of the URG, and in particular in this case the Heidelberg Basin. The cause for the start of a new cycle could also have been controlled by climatic conditions because periglacial environmental conditions were required to make these sediments available, particularly the coarse clastic sediments, which then accumulated in proximal locations. The interaction of sea level rises and falls on accumulation behaviour in the URG needs to 
Table 3: Selected boreholes from the Viernheim-Bensheim area with the depths of the characteristic marker horizons. Petrographic descriptions of the flush drilled wells are uncertain.

Tab. 3: Ausgewählte Bohrungen aus dem Raum Viernheim-Bensheim mit der Tiefenlage charakteristischer Leithorizonte. Die petrographischen Beschreibungen der Spülbohrungen sind unsicher.

\begin{tabular}{|c|c|c|c|c|c|c|}
\hline $\begin{array}{l}\text { No. } \\
\text { (Fig. 10) }\end{array}$ & $\begin{array}{l}\text { Identifier } \\
\text { Drilling method } \\
\text { total depth (TD) }\end{array}$ & $\begin{array}{c}\text { Gamma } \\
\text { logging }\end{array}$ & $\begin{array}{l}\text { Top } \\
\text { layer Xb } \\
{[\mathrm{m}]}\end{array}$ & $\begin{array}{l}\text { Base } \\
\text { layer Xb } \\
{[\mathrm{m}]}\end{array}$ & $\begin{array}{l}\text { Thickness layer } \\
\mathrm{Xb}[\mathrm{m}]\end{array}$ & $\begin{array}{l}\text { Base of the } \\
\text { Quaternary } \\
\text { sediments }[\mathrm{m}]\end{array}$ \\
\hline 1 & $\begin{array}{l}\text { Deponie Hirschländer } \\
\text { GWM1/03 } \\
\text { dry drilling; TD } 80 \mathrm{~m}\end{array}$ & - & 46 & 60 & 24 & - \\
\hline 2 & $\begin{array}{l}\text { EWS Viernheim 2006/ } \\
780 \\
\text { flush drilling } \\
\text { (petrography uncertain); } \\
\text { TD } 300 \mathrm{~m}\end{array}$ & - & $?$ & $?$ & $?$ & $297 ?$ \\
\hline 3 & $\begin{array}{l}\text { EWS Viernheim 2006/ } \\
594 \text { (2008) } \\
\text { flush drilling; TD } 140 \mathrm{~m}\end{array}$ & $X$ & 45.5 & 65 & 19.5 & - \\
\hline 4 & $\begin{array}{l}\text { STW Viernheim } \\
\text { tube core drilling and } \\
\text { flush drilling; } \\
\text { TD } 110 \mathrm{~m}\end{array}$ & $X$ & 42.25 & 62.15 & 19.9 & - \\
\hline 5 & $\begin{array}{l}\text { FB Viernheim B1/06 } \\
\text { tube core drilling; TD } \\
350 \mathrm{~m}\end{array}$ & $X$ & 39.76 & 58.55 & 18.79 & 225 \\
\hline 6 & $\begin{array}{l}\text { EWS Hüttenfeld 2007/ } \\
581 \\
\text { flush drilling; TD } 99 \mathrm{~m}\end{array}$ & $X$ & 43 & 60 & 17 & - \\
\hline 7 & $\begin{array}{l}\text { FB Einhausen C/01-BK4 } \\
\text { tube core drilling; TD } \\
205 \mathrm{~m}\end{array}$ & $X$ & - & - & 0 & 164.8 \\
\hline 8 & $\begin{array}{l}\text { WW Feuersteinberg } \\
\text { GWM 75t } \\
\text { flush drilling; TD } 65 \mathrm{~m}\end{array}$ & $X$ & 35 & 45 & 10 & - \\
\hline
\end{tabular}




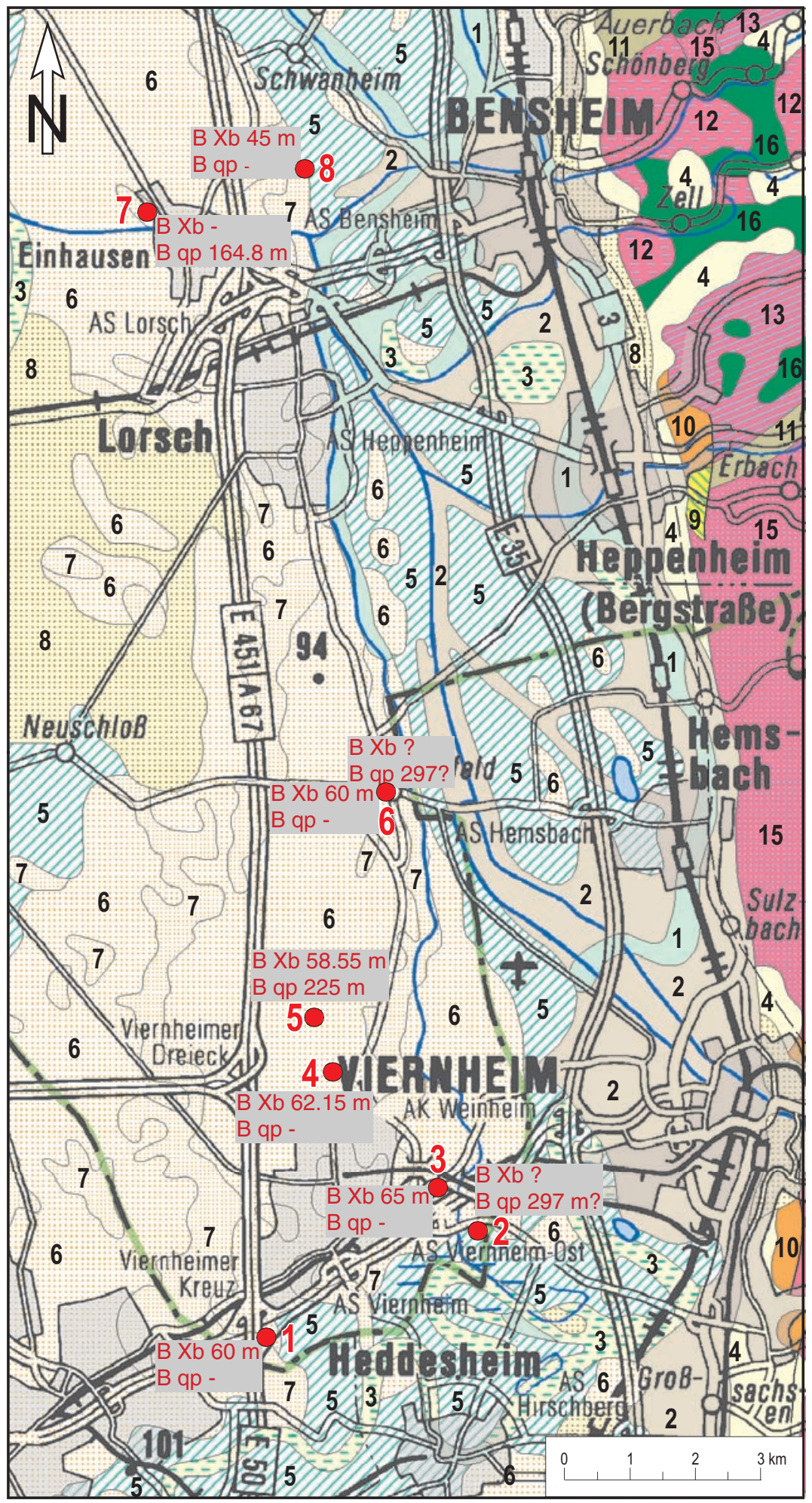




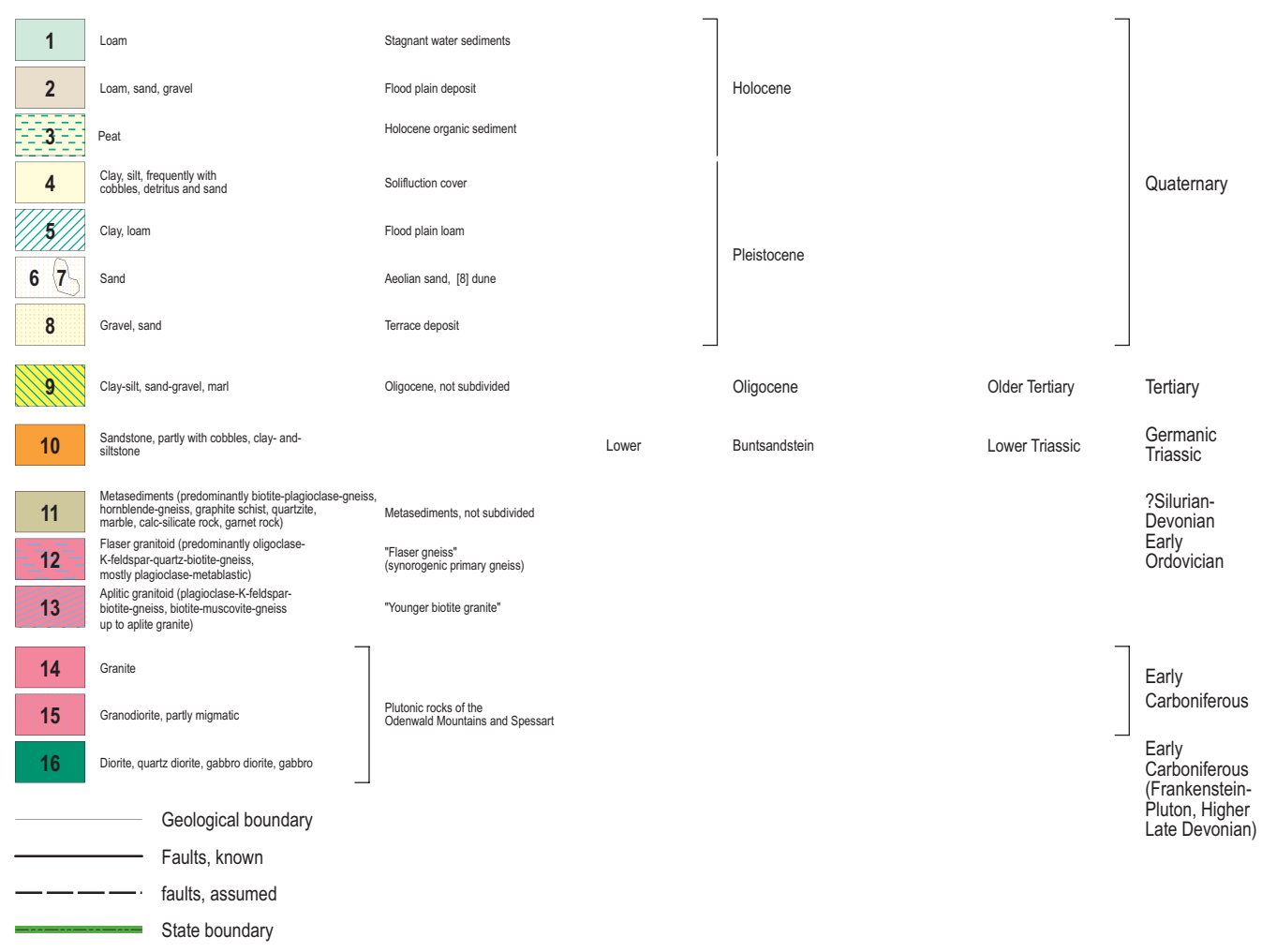

Scientific editing by members of the "Hessisches Landesamt für Umwelt und Geologie"

Status: 5. revised, digital edition; August 2007

Base data: General geological map of Hessen at a scale of 1:300,000 (1.-3. edition of F. RösING) and geological maps at a scale of 1:25,000

Topographic base of the map: Hessen at a scale of 1:200,000 (H200) reproduced with permission of the "Hessisches Landesamt für Bodenmanagement und Geoinformation". Verv.-Nr: 2006-3-81

(c) Hessisches Landesamt für Umwelt und Geologie, Wiesbaden 2007

Diese Karte ist gesetzlich geschützt. Vervielfältigung nur mit Erlaubnis des Herausgebers. Als Vervielfältigung gelten z.B. Nachdruck, Fotokopie, Mikroverfilmung, Digitalisierung, Scannen sowie Speicherung auf Datenträgern.

Fig. 10: Distribution of various boreholes drilled recently in the southern Hessisches Ried used to evaluate "regional trends". The well locations are plotted on the geological base map of Hessen 1:300,000. The graben margin at the boundary to the crystalline Odenwald can be seen in the eastern part of the map; in the southeast with sedimentary rock remains of the lower Buntsandstein.

$\mathrm{B} \mathrm{Xb}=$ Base section $\mathrm{Xb}$ in $\mathrm{m}$ below ground level; $\mathrm{B} \mathrm{qp}=$ Base Pleistocene in $\mathrm{m}$ below ground level

Abb. 10: Verteilung verschiedener in den letzten Jahren abgeteufter Bohrungen im südlichen Hessischen Ried, die für die Auswertung ,regionaler Trends” verwendet wurden. Die Bohransatzpunkte wurden in die Geologische Übersichtskarte 1:300.000 von Hessen eingetragen. Im östlichen Teil des Kartenausschnitts ist an der Grenze zum kristallinen Odenwald der Grabenrand zu erkennen; im Südosten mit Sedimentgesteinsresten des unteren Buntsandsteins.

$\mathrm{B} \mathrm{Xb}=$ Basis Sequenz $\mathrm{Xb}$ in $\mathrm{m}$ unter $\mathrm{GOK}$; $\mathrm{B} \mathrm{qp}=$ Basis Pleistozän in $\mathrm{m}$ unter GOK 
be clarified for this purpose. Rapid rises in sea level can also cause water to back up in the hinterland and possibly trap accumulation in front of the rising Rhenish Massif and lead to increased coarse clastic sedimentation in the southern Upper Rhine Graben and in the northern URG north of the Karlsruhe High to dominant fine-clastic sedimentation. Answering these questions requires detailed analysis of cores in the Heidelberg Basin because understanding the depositional processes and palaeogeographic development of this region and the fluviatile Rhine system is only possible in the high resolution deposits which are only found here in the thickest Quaternary sedimentary succession in the URG.

\section{Acknowledgements}

The research borehole project in the Heidelberg Basin was only possible by the co-operation between the HLUG and the Geological Surveys in Baden-Württemberg (Dietrich Ellwanger, Theo Simon, Eckhard Villinger, and Ulrike Wielandt-Schuster) and Rheinland-Pfalz (Michael Weidenfeller), and the Leibniz Institute for Applied Geosciences (Hermann Buness, Manfred Frechen, Gerald Gabriel, Christian Rolf, Thomas Wonik, and Kathrin Worm). This co-operation was also beneficial thanks to the many discussions and ideas it engendered. Thanks go to Roman Haimberger (now 360plus Consult $\mathrm{GmbH}$, Karlsruhe) for many years of friendly co-operation. Credit also goes to Michaela Dersch-Hansmann, Heiner Heggemann, Heinz-Dieter Nesbor and Joachim Wedel (all HLUG), Carl-Peter Ziehlke (formerly HLUG), and Markus Diehl (TU Darmstadt) for their project assistance and numerous ideas. Markus Fiebig and Jef Vandenberghe are thanked for their critical and constructive reviews of the manuscript.

\section{References}

Anderle, H.-J. \& Golwer, A. (1980): Tektonik. - In: Erläuterungen zur Geologischen Karte von Hessen 1 : 25 000, Blatt Nr. 5917 Kelsterbach:
50-64, Hessisches Landesamt für Bodenforschung.

BARTZ, J. (1974): Die Mächtigkeit des Quartärs im Oberrheingraben. - In: Fuchs, K. \& Illies, J.H. (eds.): Approaches to Taphrogenesis. - InterUnion Commission on Geodynamics Scientific Report, 8: 78-87; Stuttgart (Schweizerbart).

BARTZ, J. (1982): Quartär und Jungtertiär II im Oberrheingraben im Großraum Karlsruhe mit Beiträgen von Brelie, G. von der \& Maus, $\mathrm{H}$. - Geologisches Jahrbuch, A 63: 3-237.

Bibus, E. (1980): Zur Relief-, Boden- und Sedimententwicklung am unteren Mittelrhein. - Frankfurter Geowissenschaftliche Arbeiten, Serie D, 1: $296 \mathrm{pp}$.

Bibus, E. \& Semmel, A. (1977): Über die Auswirkung quartärer Tektonik auf die altpleistozänen Mittelrhein-Terrassen. - Catena, 4: 385-408.

Boenigk, W. (1977/78): Zur petrographischen Gliederung der Mosbacher Sande im Dyckerhoff-Steinbruch, Wiesbaden/Hessen. - Mainzer Naturwissenschaftliches Archiv, 16: 91-126.

Boenigk, W. (1983): Schwermineralanalyse. - 152 pp.; Stuttgart (Enke).

Boenigk, W. (1987): Petrographische Untersuchungen jungtertiärer und quartärer Sedimente am linken Oberrhein. - Jahresberichte und Mitteilungen des Oberrheinischen Geologischen Vereines, N.F. 69: 357-394.

Boenigk, W. \& Frechen, M. (2006): The Pliocene and Quaternary fluvial archives of the Rhine system. - Quaternary Science Reviews, 25(5-6): 550-574.

Boenigk, W. \& Hoselmann, C. (1991): Zur Genese der Hönninger Sande (unterer Mittelrhein). - Eiszeitalter und Gegenwart, 41: 1-15.

BogaArd, P. VAn den \& SchmincKe, H.U. (1990): Die Entwicklungsgeschichte des Mittelrheinraumes und die Eruptionsgeschichte des Osteifel-Vulkanfeldes. - In: SCHIRMER, W. (ed.): Rheingeschichte zwischen Mosel und Maas. - deuqua-Führer; 1: 166-190; Hannover.

Bos, J.A.A., Dambeck, R., Kalis, A.J., Schweizer, A. \& Thiemeyer, H. (2008): Palaeoenvironmental changes and vegetation history of the northern Upper Rhine graben (southwestern Germany) since the Lateglacial. - Netherlands Journal of Geosciences, 87(1): 67-90.

Bowen, D.Q. \& GibBard, P.L. (2007): The Quaternary is here to stay. - Journal of Quaternary Science, 22(1): 3-8.

DAMBECK, R. (2005): Beiträge zur spät- und postglazialen Fluß- und Landschaftsentwicklung 
im nördlichen Oberrheingraben. - Diss. Fb Geowiss./Geogr. Univ. Frankfurt a. M.: 246 pp.; Frankfurt a. M. (online-publication - URL: http: //publikationen.ub.uni-frankfurt.de/volltexte/ 2005/908/).

DAmbeck, R. \& Bos, J.A.A. (2002): Lateglacial and Holocene Landscape evolution of the northern Upper Rhine-Rift-Valley. - Zeitschrift für Geomorphologie Neue Folge, Supplement-Band, 128: 101-127.

DAmBeck, R. \& Thiemeyer, H. (2002): Fluvial History of the northern Upper Rhine river (south-western Germany) during the Lateglacial and Holocene Times. - Quaternary International, 93/94: 53-63.

Dehnert, A. \& Schlüchter, C. (2008): Sediment burial dating using terrestrial cosmogenic nuclides. - Quaternary Science Journal (Eiszeitalter und Gegenwart), 57/1-2: 210-225.

Donders, T.H., Kloosterboer-van Hoeve, M.L., WesterhofF, W.E., Verreussel, R.M.C.H. \& LotTer, A.F. (2007): Late Neogene continental stages in NW Europe revisted. - Earth-Science Reviews, 85: 161-186.

Ellwanger, D., Gabriel, G., Simon, T. WielandtSchuster, U., Geiling, R.O., Hagedorn, E.-M., Hahne, J. \& Heinz, J. (2008): Long sequence of Quaternary Rocks in the Heidelberg Depocentre. - Quaternary Science Journal (Eiszeitalter und Gegenwart): 57/3-4: 316-337.

Ellwanger, D., Gabriel, G., Hoselmann, C., LÄMmermann-Barthel, J. \& Weidenfeller, M. (2005): The Heidelberg Drilling Project (Upper Rhine Graben, Germany). - Quaternaire, 16(3): 191-199.

Engesser, W. \& Münzing, K. (1991): Molluskenfaunen aus Bohrungen im Raum Phillipsburg-Mannheim und ihre Bedeutung für die Quartärstratigraphie des Oberrheingrabens. - Jahreshefte des Geologischen Landesamts Baden-Württemberg, 33: 97-117.

Erkens, G., Dambeck, R., Volleberg, K.P., Bouman, M.T.I.J., Bos, J.A.A., CoHEN, K.M., WAlLINGA, J. \& HoEk, W.Z. (2009): Fluvial terrace formation in the northern Upper Rhine Graben during the last 20000 years as a result of allogenic controls and autogenic evolution. - Geomorphology, 103(3): 476-495.

Geyн, M. (2008): ${ }^{230} \mathrm{Th} / \mathrm{U}$ dating of interglacial and interstadial fen peat and lignite: Potential and limits. - Quaternary Science Journal (Eiszeitalter und Gegenwart), 57/1-2: 77-94.

GibBard, P. \& Cohen, K.M. (2008): Global chronostratigraphical correlation table for the last 2.7 million years. - Episodes, 31(2): 243-247.

Hagedorn, E.-M. (2004): Sedimentpetrographie und Lithofazies der jungtertiären und quartären Sedimente im Oberrheingebiet. - Inaugural-Dissertation, Geologisches Institut der Universität zu Köln: 248 pp.; (online-publication - URL: http: //kups.ub.unikoeln.de/volltexte/2004/1253/).

Hagedorn, E.-M. \& Boenigk, W. (2008): New evidences of the Pliocene and Quaternary sedimentary and fluvial history in the Upper Rhine Graben on basis of heavy mineral analyses. - Netherlands Journal of Geosciences, 87(1): 19-30.

Haimberger, R., Hoppe, A. \& Schäfer, A. (2005): High-resolution seismic survey on the Rhine River in the northern Upper Rhine Graben. - International Journal of Earth Sciences (Geologische Rundschau), 94(4): 657-668.

HGK (1999): Hydrogeologische Kartierung und Grundwasserbewirtschaftung Rhein-NeckarRaum. Fortschreibung 1983-1999. - Ministerium für Umwelt und Verkehr Baden-Württemberg, Hessisches Ministerium für Umwelt, Landwirtschaft und Forsten, Ministerium für Umwelt und Forsten Rheinland-Pfalz: 155 pp.; Stuttgart, Wiesbaden, Mainz.

Hoselmann, C. (1996): Der Hauptterrassen-Komplex am unteren Mittelrhein. - Zeitschrift Deutsche Geologische Gesellschaft, 147(4): 481-497.

Hoselmann, C. (2007a): Untermain-HauptterrassenFormation. - In: LithoLex [Online-database]. Hannover: BGR. Last updated 13.11.2007. [cited 02.05.2007]. Record No. 1000003. Available from: http://www.bgr.bund.de/DE/Themen/GG Palaeontol/LithoLex.

Hoselmann, C. (2007b): Haupt-Mosbach-Subformation. - In: LithoLex [Online-database]. Hannover: BGR. Last updated 13.11.2007. [cited 27.04.2007]. Record No. 1000001. Available from: http://www.bgr.bund.de/DE/Themen/ GG Palaeontol/LithoLex.

KAHLKE, R.-D. (2007): Late Early Pleistocene European large mammals and the concept of an Epivillafranchian biochron. - Courier Forschungsinstitut Senckenberg, 259: 265-278.

KeLLER, T. (1999): Fundstellen von Kleinsäugern in den mittelpleistozänen Mosbach-Sanden. - Jahrbücher des nassauischen Vereins für Naturkunde, 120: 167-171.

Kemna, H.A. (2005): Pliocene and Lower Pleistocene Stratigraphy in the Lower Rhine Embayment, Germany. - Kölner Forum für Geologie und Paläontologie, 14: 1-121. 
Kemna, H.A. (2008a): A Revised Stratigraphy for the Pliocene and Lower Pleistocene Deposits of the Lower Rhine Embayment. - Netherlands Journal of Geosciences, 87(1): 91-105.

Kemna, H.A. (2008b): Pliocene and Lower Pleistocene fluvial history of the Lower Rhine Embayment, Germany: Examples of the tectonic forcing of river courses. - Quaternary International, 189: 106-114.

Kemna, H.A. \& Westerhoff, W.E. (2007): Remarks on the palynology-based chronostratigraphical subdivision of Pliocene terrestrial deposits in NW-Europe. - Quaternary International, 164165: 184-196.

KnIPPING, M. (2004): Pollenanalytische Untersuchungen an einem mittelpleistozänen Interglazial bei Mannheim. - Tübinger Geowissenschaftliche Arbeiten, D 10: 199-217.

KNIPPING, M. (2008): Early and Middle Pleistocene pollen assemblages of deep core drillings in the northern Upper Rhine Graben, Germany. - Netherlands Journal of Geosciences, 87(1): 49-63.

LANG, S. (2007): Die geologische Entwicklung der Hanau-Seligenstädter Senke (Hessen, Bayern). - Dissertation an der Technischen Universität Darmstadt: 97 pp.; (online-publication - URL: http://elib.tu-darmstadt.de/diss/000782/).

LiTT, T. (2007): Das Quartär als chronostratigraphische Einheit - The Quaternary as a chronostratigraphical unit. - Quaternary Science Journal (Eiszeitalter und Gegenwart): 56/1-2: 3-6.

LöSCHER, M. (1988): Stratigraphische Interpretation der jungpleistozänen Sedimente in der Oberrheinebene zwischen Bruchsal und Worms. - In: Koenigswald, W. von (ed.): Zur Paläoklimatologie des letzten Interglazials im Nordteil der Oberrheinebene: 79-104; Stuttgart (Fischer).

Peters, G., Buchmann, T.J., Connolly, P., Van Balen, R.T., Wenzel, F. \& Cloetingh, S.A.P.L. (2005): Interplay between tectonic, fluvial and erosional processes along the Western Border Fault of the northern Upper Rhine Graben, Germany. - Tectonophysics, 406: 39-66.

Peters, G. \& Van Balen, R.T. (2007a): Pleistocene tectonics inferred from fluvial terraces of the northern Upper Rhine Graben, Germany. - Tectonophysics, 430: 41-65.

Peters, G. \& Van Balen, R.T. (2007b): Tectonic geomorphology of the northern Upper Rhine Graben, Germany. - Global Planetary Change, 58: 310-334.
Preusser, F. (2008): Characterisation and evolution of the River Rhine system. - Netherlands Journal of Geosciences, 87(1): 5-17.

Preusser, F., Deggering, D., Fuchs, M., Hilgers, A., Kadereit, A. Klasen, N. Krbetschek, M., Richter, D. \& SPENCER, J.Q.G. (2008): Luminescence dating: basics, methods and applications. - Quaternary Science Journal (Eiszeitalter und Gegenwart), 57/1-2: 95-149.

Rolf, C., Hambach, U. \& Weidenfeller, M. (2008): Rock and palaeomagnetic evidence for the PlioPleistocene palaeoclimatic change recorded in Upper Rhine Graben sediments (Core Ludwigshafen-Parkinsel). - Netherlands Journal of Geosciences, 87(1): 39-48.

VAN ANDEL, T.H. (1950): Provenance, Transport and Deposition of Rhine Sediments. - 129 pp., Wageningen (Veenman \& Zonen).

VAN GiJsSel, K. (2006): A continent-wide framework for local and regional stratigraphies. - Doctoral thesis, Leiden University: 119 pp.; (online-publication - URL: https://openaccess.leidenuniv.nl/ dspace/handle/1887/4985).

VIllinger, E. (2005): Symbolschlüssel Geologie Baden-Württemberg - Regelwerk für eine einheitliche Nomenklatur. - LGRB-Informationen, 17: 8-24.

VInKEN, R. (1959): Sedimentpetrographische Untersuchungen der Rheinterrassen im östlichen Teil der Niederrheinischen Bucht. - Fortschritte in der Geologie von Rheinland und Westfalen, 4: 127-170.

Wedel, J. (2008): Pleistocene molluscs from research boreholes in the Heidelberg Basin. - Quaternary Science Journal (Eiszeitalter und Gegenwart): 57/3-4: 382-402.

WeidenfelLer, M. (2007): Mittelrhein-Hauptterrassen-Formation. - In: LithoLex [Online-database]. Hannover: BGR. Last updated 13.11.2007. [cited 2.05.2007]. Record No. 1000004. Available from: http://www.bgr.bund.de/DE/ Themen/GG Palaeontol/LithoLex.

Weidenfeller, M. \& Kärcher, T. (2008): Tectonic influence on fluvial preservation: Aspects of the architecture of Middle and Late Pleistocene sediments in the northern Upper Rhine Graben, Germany. - Netherlands Journal of Geosciences, 87(1): 31-38.

Weidenfeller, M. \& Knipping, M. (2008): Correlation of Pleistocene sediments from boreholes in the Ludwigshafen area, western Heidelberg Basin. - Quaternary Science Journal (Eiszeitalter und Gegenwart): 57/3-4: 270-286. 
Westerhoff, W.E. (2008): The Rhine - a major fluvial record. - Netherlands Journal of Geosciences, 87(1): 1-4.

Westerhoff, W.E., Kemna, H.A. \& Boenigk, W. (2008): The confluence area of Rhine, Meuse, and Belgian rivers: Late Pliocene and Early Pleistocene fluvial history of the northern Lower
Rhine Embayment. - Netherlands Journal of Geosciences, 87(1): 107-125.

Wirsing, G., Lutz, A., Engesser, W. \& Koch, A. (2007): Hochauflösende Reflexionsseismik auf dem Rhein und dem Rheinseitenkanal zwischen Mannheim und Rheinfelden. - LGRB-Fachbericht, 1/07: 60 pp.; Freiburg i. Br. 